AperTO - Archivio Istituzionale Open Access dell'Università di Torino

\title{
Sociability, Altruism and Well-Being
}

\section{This is the author's manuscript}

Original Citation:

Availability:

This version is available http://hdl.handle.net/2318/135439

since 2017-05-30T16:41:20Z

Published version:

DOI:10.1093/cje/bew033

Terms of use:

Open Access

Anyone can freely access the full text of works made available as "Open Access". Works made available under a Creative Commons license can be used according to the terms and conditions of said license. Use of all other works requires consent of the right holder (author or publisher) if not exempted from copyright protection by the applicable law. 


\title{
Department of Economics and Statistics \\ "COGNETTI DE MARTIIS"
}

\section{Working Paper Series}

\section{$14 / 13$}

\author{
SOCIABILITY, ALTRUISM AND \\ SUBJECTIVE WELL-BEING
}

\section{LEONARDO BECCHETTI, LUISA CORRADO and PIERLUIGI CONZO}





\title{
Sociability, Altruism and Subjective Well-Being
}

\author{
By Leonardo Becchetti", Luisa Corrado, Pierluigi Conzo ${ }^{\dagger}$
}

• Dept. of Economics, University of Rome Tor Vergata, Via Columbia 2, I-00133 Roma; email: becchetti@economia.uniroma2.it

‡ University of Rome Tor Vergata and CreMic CIMF, University of Cambridge

${ }^{\dagger}$ Dept. of Economics and Statistics "Cognetti de Martiis", University of Turin

This version: March 2013

\begin{abstract}
We provide non experimental evidence of the relevance of sociability on subjective wellbeing by investigating the determinants of life satisfaction on a large sample of Europeans aged above 50. We document that voluntary work, religious attendance, helping friends/neighbours and participation to community-related organizations affect positively and significantly life satisfaction. We illustrate the different impact that some sociability variables have on eudaimonic versus cognitive measures of subjective wellbeing. Our empirical findings discriminate among other regarding and self-regarding preferences as rationales explaining such behaviour. We document that different combinations between actions and motivations have different impact on life satisfaction thereby providing support for the relevance of these specific "contingent goods" and to the literature of procedural utility. Our findings are confirmed in robustness checks including refinements of the dependent variable, instrumental variables and sensitivity analysis on departures from the exogeneity assumption.
\end{abstract}

Keywords: sociability, altruism, other-regarding activities, other regarding motivations, life satisfaction, subjective well-being.

JEL Numbers: A13, D13, D64. 


\section{Introduction}

One of the most relevant topics in the current economic debate is the thorough discussion and the renewed interest on fundamentals of human preferences, after the challenge posed to the traditional anthropological approach of mainstream economics by the emerging articulated body of empirical findings in experimental economics. ${ }^{1}$ Binmore and Shaked (2010) frame the question by correctly arguing that this is not a problem concerning rationality and the utility maximizing approach since the standard theory is perfectly fit to accommodate other regarding arguments in its utility functions. ${ }^{2}$ The two authors defend the standard theory by arguing that no "selfishness axiom" appears in standard textbooks (as it sometimes seems to be implied, according to the same authors, by experimentalists) and that, following Samuelson, neoclassical theorists think it is a virtue "not to be committed to any particular view of how human minds work". Back to the words of Binmore and Shaked the methodology "remains the same whether [players in game theory] are Attila the Hun or St. Francis of Assisi."

However, anytime a theoretician creates an economic model and a utility function, by selecting some arguments instead of others, (s)he is implicitly committing to a particular view of the human being. A related problem with this is that the adoption of a "reductionist" approach on human preferences has been widely shown to be socially harmful in presence of the well-known social dilemmas which typically arise in the standard framework in which business and social relationships occur. In presence of asymmetric information, incomplete contracts and limited efficiency of civil justice, coordination failures in thin market situations such as those depicted in prisoner's dilemmas, trust games and traveller's games are quite common. In such situations purely self-regarding attitudes produce suboptimal individual and social outcomes which are inferior to those generated by other regarding (i.e. team or wethinking) attitudes (Becchetti, 2011a). ${ }^{3}$

\footnotetext{
${ }^{1}$ We refer to evidence coming from Dictator Games (Andreoni and Miller, 2002), Ultimatum games (Güth et al., 1982; Camerer and Thaler, 1995), Gift Exchange Games (Fehr et al., 1993; Fehr et al., 1998), Trust Games (Berg et al. 1995; Ben-Ner and Putterman, 2006) and Public Good Games (Fischbacher et al., 2001, Sonnemans et al., 1999; Fehr and Gächter, 2000). Such evidence has identified fairness, inequity aversion, pure and impure altruism and reciprocity as some of the main departures from the purely self-regarding preference paradigm.

2 There is obviously long tradition in considering other-regarding preferences as one of the arguments of individual utility even before the surge of behavioural economics. See, for instance, the literature on Ricardian equivalence and bequests (Leiderman and Bleier, 1988).

3 The paradox is that even game theorists have been demonstrated as experiment participants not to follow standard Nash rationality but rather prefer (even in one shot simultaneous games) cooperative strategies which can lead to superior outcomes when facing social dilemmas (see for instance their behavior in Travellers' Games in Becker et al., 2005).
} 
In addition to it, modeling individuals as purely selfish is a problem since empirical evidence from i) donations, ii) voluntary work, iii) experiments, iv) revealed preferences of consumers and investors paying ethical premia and v) life satisfaction studies tells us something different.

Official data document that around 90 percent of US citizens donated money in 2009 (for a total amount of $\$ 303.75$ billion, around 2\% of GDP) (Giving USA, 2010), while around 26 percent volunteered by "working for nothing" in a not for profit organization. ${ }^{4}$ According to Gallup and OECD (2008) data the two countries with the highest share of officially volunteering population are Canada (38.1 percent) and Australia (37.9), while it is reasonable to assume that figures are much higher if we include voluntary activities performed outside registered not for profit organisations. The ILO has recently launched a world initiative to measure the impact of voluntary work by publishing a manual of accounting standards which should be adopted by national statistical institutes. In its introduction the manual reports that 12 percent of the adult population of 37 main world countries (140 million people) volunteer (representing the equivalent of 20.8 million full-time equivalent paid workers) and generating a $\$ 400$ billion contribution to the global economy according to conservative estimates (Salamon et al., 2004). More important to our investigation on life satisfaction and other regarding preferences is that, according to ILO, "Volunteer work provides a sense of personal satisfaction, fulfillment, well-being and belonging to persons who volunteer."

As it is well known donations and voluntary work may, in part, depend on strategic reasons (Andreoni, 1989 and 1990; Harbaugh, 1998; Goeree et al., 2002; Ribar and Wilhelm, 2002; see also Camerer, 2003, for a comprehensive review). Individuals may donate since they expect something back in exchange, even though, by donating they run the "social risk" of not being reciprocated. Another reason for donating is to gain social appraisal. Furthermore, voluntary work may be explained by the desire to improve one's own social network or as a form of apprenticeship which may increase future employment opportunities. This is one of the reasons why the analysis done in this paper (which combines actions and motivations) is of foremost importance. All individuals in the SHARE survey are aged above 50 and therefore the employment motivation of other-regarding activities (i.e., for instance voluntary work) may be generally excluded for the large share of retired individuals in our sample. In the empirical analysis which follows we will consider the hypothesis of strategic reasons behind voluntary activity by testing whether the behavior of retired versus non-retired individuals differs in our sample.

${ }^{4}$ http://philanthropy.com/article/26-of-Americans-Volunteer/62876/ 
Another branch of empirical evidence which may be related to other regarding preferences is that of ethical premia paid by consumers on socially and environmentally responsible products. A recent global Survey by Nielsen on a sample of 28,000 consumers in 56 countries (Nielsen, 2012) calculates that 46 percent are willing to pay a premium price for companies adopting corporate social responsibility strategies. As is well known, even though the contingent evaluation literature tells us that such share falls when it comes to actual choices, revealed preferences on market share of products incorporating social and environmental premia, however, document that actual consumer behavior is affected by such willingness to pay. ${ }^{5}$

With regard to experimental evidence, one the most systematic documentation on other regarding preferences is that on dictator games. A meta paper by Engels (2010) resumes findings from 328 different Dictator game experiments for a total of 20,813 observations and finds that individuals following Nash rationality (giving zero) are around one third (36 percent). The share drops significantly once we eliminate students from the sample ${ }^{6}$ (up to 20 percent in case of children and 10 percent in case of middle aged players). An important component of other-regarding attitudes is related to the desire to maintain good relationships and therefore departures from the purely self regarding model are larger when social distance is reduced (Andreoni and Bernheim, 2009; Broberg et al., 2005; Dana et al., 2006). ${ }^{7}$ Overall, the experimental literature has widely documented significant departures from the purely self-regarding paradigm for the majority of individuals. We can therefore share Engel's conclusions that "While normally a sizeable fraction of participants does indeed give nothing, as predicted by the payoff maximisation hypothesis, only very rarely this has been the majority choice. It is by now undisputed that human populations are systematically more benevolent than homo oeconomicus". 8

\footnotetext{
${ }^{5}$ For a survey on the contingent claim literature see Carson et al. (2001).

${ }^{6}$ Additional evidence on the fact that students are significantly more selfish (more inequity averse and less trusting) in experiments is recently provided by Belot et al. (2010).

${ }^{7}$ A good synthesis on this point is provided by Konow (2010) who argues that giving arises from a mix of unconditional and conditional altruism where the latter is related to context dependent norms where need can be more important than familiarity with the receiver.

${ }^{8}$ Recent advancements demonstrate that results may change if the structure of the game is modified. List (2007) documents that individuals are more selfish when they also have the opportunity of taking and not just giving, even though the result that they do not choose the most selfish solution is confirmed. Furthermore, there is widespread evidence that they behave more selfishly when their endowments are deserved with effort or talent and are not a gift given by experimenters (Becchetti et al., 2011c).
} 
Note, however, that in their well-known controversy with behavioural economists Binmore and Shaked stress that lab evidence of departures from the purely self regarding paradigm does not imply that individuals have other regarding preferences. Their main arguments to confute such interpretation are that: i) when games are repeated individuals tend to converge toward Nash equilibria; ii) individuals are purely self regarding and maximize their utility but keeping into account constraints of social norms. Since departures from social norms are psychologically (or economically) costly they do not deviate from them. When entering in the lab they behave as having other regarding preferences because they believe that there is a social norm to apply which asks to do so (Binmore and Shaked, 2010). Hence, according to this view, purely self regarding preferences and Folk theorems in repeated games are enough to explain what observed in the lab.

\subsection{Contribution of our paper}

This controversy suggests that two important steps forward in this debate testing may consist of testing the hypothesis that other regarding behavior positively affects life satisfaction and discriminating between other regarding preferences and compliance to social norms as potential rationales for the observed other regarding behavior. This is what we try to do in our paper. More specifically, our assumption is that the existence of other regarding preferences cannot be rejected if we document that other regarding activities performed with other regarding motivations increase life satisfaction and are robust to changes in local social norms on the same activities.

The main limit of the highly valuable experimental evidence about other regarding preferences is that of external consistency. What happens in labs may be quite different from what happens in the reality. One of the reasons is that money in lab is added to participants wealth while generosity in real life implies detracting resources from one's own budget. Moreover most lab experiments are with students and it is therefore often wondered whether the same findings apply to other individuals. If, on the other side, we consider evidences mentioned in the introduction on voluntary work and revealed preferences on ethical premia paid by consumers, we observe that such evidence does not disentangle the causality problem of the nexus between sociability and life satisfaction. A reverse causation link may in fact not be ruled out since satisfaction with life may stimulate other regarding behavior. This is why it 
is important to find also "externally consistent" non experimental evidence of other regarding preferences with a rigorous check of the causality link as we try to do in our paper.

In our empirical analysis on Europeans aged above 50 we first document the significant positive correlation between other regarding activities and life satisfaction and its robustness to different measures of the dependent variable. ${ }^{9}$ We then discriminate among three plausible explanations of our findings, i.e. compliance to social norms, self and other regarding preferences. More specifically, by exploiting information on motivations behind voluntary/charity work and helping friends/neighbours, we find that the effect is positive and significant when these two actions are motivated by other regarding rationales (i.e. because I'm needed and/or to contribute to something useful), while it is not so in presence of non other regarding rationales. We then document that our main result is also robust in regions with high/low social norms related to the specific activity and to changes in the measure of subjective wellbeing. Finally, we demonstrate that the correlation is confirmed in robustness checks including instrumental variables and sensitivity analysis on departures from the exogeneity assumption.

Hence our paper relates to the literature on subjective wellbeing and sociability. This literature, however, has mainly focused on the impact of social relationships on life satisfaction (Meier and Stutzer, 2008; Becchetti et al. 2008 and 2011b Clark and Lelkes, 2009) ${ }^{10}$ while the contribution of our paper is on the specific focus of the correlation (and causality nexus) between other regarding social activities animated by other regarding motivations and different measures of subjective wellbeing.

A further original feature of our work is that the "stimulus good" under our inquiry is a form of contingent good generated by the interaction between an action and a motivation. In this sense the paper both contributes to the contingent good literature and provides support to the procedural utility hypothesis set forth by Frey and Stutzer (2005) arguing that what

\footnotetext{
${ }^{9}$ A related interesting finding in what follows is that another other regarding activity such as caring for the sick/elderly affects negatively our standard cognitive measure of subjective wellbeing (life satisfaction) but positively an eudaimonic measure of subjective wellbeing (declaration that life has a meaning). See, among others, Ryff and Singer (2006) for details on the concept of eudaimonic happiness.

${ }^{10}$ Bilancini and Sarracino (2011) document that long term changes in sociability largely predict changes in wellbeing in Germany, while Bartolini et al. (2012) find support for the Putnam's (2000) "bowling alone" argument by showing that the decline in the US social capital (especially the intrinsically motivated component measured by Olson's associations) predicts an important part of the unexplained Easterlin's paradox in the 1975-2004 period.
} 
matters for individual utility is not just the outcome of an action but also the process and all its characteristics (in our case the underlying motivations behind individual actions).

The paper is divided into seven sections (including introduction and conclusions). In the second section we describe our database and illustrate the descriptive statistics of our main variables of interest. In the third section we outline our model specification. In section four we present our econometric findings and some robustness checks. In the fifth section we provide an in-depth analysis of our findings to discriminate among three different explanations (compliance to social norms, self regarding and other regarding preferences). In the sixth section we use instrumental variables and sensitivity analysis to document the direct causality nexus between other regarding activities performed with other regarding motivations and life satisfaction. Section seven concludes.

\section{Variable description and general statistics}

We use data from the second wave of SHARE implemented during 2006-2007. In Table 1 we report all the variables used in our analysis with a brief description. Tables $2 \mathrm{a}-2 \mathrm{~b}$ show summary statistics for the main socio-demographic and economic variables under investigation.

Interviewed people are asked how satisfied they are with their life on a scale from 0 to 10 , where 0 means completely dissatisfied and 10 completely satisfied. Figure 1 shows that the distribution of self-reported life satisfaction (variable lifesat) in our sample is right skewed with a mean of 7.54 and 77.6 percent of respondents declaring a self-reported life satisfaction above 6. A deeper inspection of life satisfaction by country highlights that the variable mean takes the highest values (i.e. above eight) for Denmark, Switzerland, Sweden and Ireland in the order (Table $2 \mathrm{~b})$.

The main variables which we consider as proxy for respondents' other regarding preferences are the activities carried out in the last month. More specifically, participants reply yes/no to the question "have you done any of these activities in the last month?" for each the following options: i) voluntary or charity work (variable voluntary in our sample); ii) cared for a sick or disabled adult (cared for sick); iii) provided help to friends or neighbours (help to friends); iv) gone to a sport, social or other kind of club (sport/social clubs); v) taken part in activities of a 
religious organization (church, synagogue, mosque etc.) (religion attendance); vi) taken part in a political or community-related organization (political participation).

To provide introductory summary information on the content of these answers we create two variables, namely at least one activity and sociability, which can be considered respectively as lower and upper bound measures of other regarding preferences. The former is equal to one if the respondent has done at least one of the listed activities, whereas the latter is the sum of the activities for which the respondent replies affirmatively and is standardized by the total number of activities (six).

Figure 2 and Table $2 \mathrm{~b}$ show for each of the above-mentioned activities the overall and bycountry percentage of people participating in such activities. Considering the full SHARE sample composed by individuals aged above 50 , almost half of the respondents declare to carry out at least one activity (46 percent), the most frequent one being the participation to sport/social clubs (20 percent), followed by helping friends (18 percent) and voluntary work (12 percent). When looking at the distribution of activities at the country level, we find that Ireland enjoys the highest score in sociability (20 percent), followed by Sweden and the Netherlands (19 percent), Denmark and Switzerland (18 percent). The rank is slightly different if we consider people carrying out at least one activity: 68 percent in Sweden, 67 percent in Denmark and 64 percent in Ireland. Interestingly, helping friends is particularly frequent in Sweden (40 percent); Denmark and Switzerland perform relatively well in terms of social and sport clubbing (41 and 34 percent respectively), while Ireland and Greece outperform in terms of religion participation (34 and 28 percent).

With respect to demographic statistics, the sample is almost perfectly balanced in terms of gender characteristics (females are almost 50 percent), while average schooling years are 10.5. Half of the sample is between 50 and 60 year old. The average household size is 2.25 (Table 2a).

\section{Hypothesis Testing and Model Specification}

A first set of hypotheses we want to test are i) the existence of a robust and significant correlation between other-regarding activities and self-declared life-satisfaction, ii) the improvement in terms of goodness of fit which can be obtained by introducing such preferences as determinants of life satisfaction. 
The first step is to check for the presence of the above mentioned correlation by regressing self-declared life satisfaction on a set of variables expected to have a significant explanatory power according to the related literature. We are aware that correlation does not imply causation and of the possible endogeneity and measurement error problems affecting our results. In the next sections we try to address these sources of bias by using a different definition of life satisfaction, instrumental variable regressions and a sensitivity-to-exogeneity assumption analysis.

The second step consists in comparing a baseline model of life satisfaction with the one augmented with proxies of other-regarding preferences. The statistics we use for this purpose are the $\mathrm{R}^{2}$, the Akaike Information Criterion (AIC) and the Bayesian Information Criterion (BIC) ${ }^{11}$. Our hypothesis that the addition of other-regarding preferences to the baseline life satisfaction model improves the goodness of fit by increasing the $\mathrm{R}^{2}$ and reducing both the AIC and BIC. Specifically, our baseline model can be described by the following linear equation:

$$
\text { Lifesat }_{i}=\alpha+\sum_{j=1}^{n} \beta_{j} X_{i j}+\varepsilon_{i}
$$

where Lifesat is the individual's self reported level of life satisfaction and the $X$ variables include $n$ regressors commonly used in the literature (see Table 1 for details on all the variables used). They include a gender dummy, years of education, household size, the number of children and grandchildren, dummies for marital status, age class dummies and dummies capturing the features of the place of residence. The SHARE database is particularly rich in terms of health-related questions so that we can control also for a large set of indicators concerning different dimensions of physical disabilities and reported illnesses. We group them into three variables which we use as synthetic indicators for health status, namely long-term illnesses, number of illnesses and limited activities. We also add a set of country dummies to control for country specific effects.

\footnotetext{
${ }^{11}$ The Akaike Information Criterion (AIC) is defined as $A I C=n \ln \left(\frac{R S S}{n}\right)+2 k$ and the Bayesian Information Criterion (BIC) as $B I C=n \ln \left(\frac{R S S}{n}\right)+n \ln (k)$, where $n$ denotes the number of observations, $k$ is the number of parameters and RSS denotes the Residual Sum of Squares. In presence of measurement error the Residual Sum of Squares will be higher, hence both the AIC and BIC will be higher indicating a poorer fit of the model. The adjusted $R^{2}$ defined as $\bar{R}^{2}=\left(1-\frac{R S S}{T S S}\right) \frac{(n-1)}{(n-k-1)}$ will be, instead, lower.
} 
A very common problem faced by users of the SHARE dataset is the large number of missing values for income and other important variables. We consider a dataset (Christelis, 2011) where the missing values are imputed with the Fully Conditional Specification method (FCS) of Van Buuren et al. (2006) ${ }^{12}$. In brief, this method generates a distribution for the missing value of a given variable conditional on the non-missing values of other variables in the dataset. This procedure generates five imputed datasets (one for each iteration) which are attached to the main SHARE dataset. ${ }^{13}$ The imputed variables we use in our model are number of children, logincome, number of grandchildren, limited activities and the above mentioned dummies for the characteristics of the area of residence. For these variables, each respondent displays five different values but for simplicity we consider an average of them across the five datasets. 14

Finally, we compare the baseline model with the augmented specification

$$
\text { Lifesat }_{i}=\alpha+\sum_{j=1}^{n} \beta_{j} X_{i j}+\sum_{k=1}^{m} \gamma_{k} W_{i k}+\varepsilon_{i}
$$

which is equal to the baseline model previously described plus a set $W$ of $m$ regressors measuring other-regarding activities. In particular, these variables are binary responses to a question on whether in the last month the respondent took care for a sick/disabled adult (caring for sick), carried out voluntary work (voluntary), religious activities (religion attendance), political activities (political participation) sport and social clubbing (sport/social clubs), helping friends or neighbours (help to friends).

\footnotetext{
${ }^{12}$ The FCS method works under the missing at random (MAR) assumption according to which each variable missingness depends only on other variables in the system and not on the values of the variable itself. In the iteration process, the initial conditions of the first iteration are derived by imputing the first variable in the system based only on the variables that are never missing (age, gender and geographic location), then the variables in the second iteration are calculated based on the first and the non-missing variables, in order to achieve a complete set of values for these initial conditions. In this calculation the fully imputed demographic variables are used as predictors for the economic variables; in the imputation of a specific wave, large part of information that comes from other waves is taken into account. The imputation in SHARE also allows an initial burn-in period in order to decrease the dependence of the chain on the initial values. Five burn-in iterations are used by evaluating the Gelman-Rubin criterion from the seventh iteration on. For more details see Christelis (2011). The imputations are estimated separately for each country (excluding Ireland) and the sample is representative of the above fifty population.

13 The imputed datasets are available from SHARE at http://cdata8.uvt.nl/sharedatadissemination/releases/show/w2\_250/Generated+Variables/Imputations/stat a.

14 This is the approach most commonly followed. As robustness check we repeated the estimations for each of the five datasets generated after the iteration process. Results do not change significantly and are omitted for reason of space but available upon request.
} 
We use these regressors as proxies of other-regarding preferences since we assume that individuals are more likely to develop such preferences when interacting with others outside the family or work environment. Some of these variables (voluntary and help to friends) are more strictly related to altruism and generosity and isolate the "sociability" component of the other-regarding preferences which is activated in out-of-family social contacts (Fehr, 2009). We speculate more on these differences in section 5.

\section{Econometric findings}

We estimate equations 1 and 2 with OLS clustering the standard errors at country level. Surveys such as SHARE are constructed in such a way that different individuals have different probabilities of inclusion in the sample. We use individual design weights to correct for this different probability of selection in the estimation. ${ }^{15}$

For each estimation we report the adjusted R-squared, AIC and BIC statistics for model selection. Results are shown in Table 3, columns 1-2. Note that, despite of the huge number of regressors we use, the Variance Inflation Factor (VIF) does not reveal multicollinearity problems. ${ }^{16}$

The first goal of our paper is testing for the existence of a link between life satisfaction and other-regarding activities as outlined in the previous section. A preliminary estimation of the correlation between the two phenomena provides us with two important results: i) the introduction of our sociability variables (Table 3, column 2-4) does not modify the coefficients of the baseline model (Table 3, column 1) while enriching the life satisfaction multidimensional concept with an invisible and very significant non-monetary component (ii) voluntary work, attendance of religion and political-related activities as well as helping friends and social/sport clubbing play a significant role explaining the variability of selfdeclared life satisfaction and are all positively and significantly correlated with it.

\footnotetext{
15 We use the individual design weights for SHARE wave 2 (w2aci). With nonlinear estimation methods, such as Ordered Probit, the use of weights should be handled with care (see also Cameron and Trivedi, 2005). We therefore check the output of our regression for indicators of non-convergence of the likelihood function (large values of coefficients and standard errors or missing standard errors). All our estimates show no indication of non-convergence.

${ }^{16}$ The VIF formula is $1 /\left(1-R^{2}\right)$ where $R^{2}$ is the R-squared obtained by regressing each independent variable on all other independent variables (Marquardt, 1970). If $R^{2}$ is low (tends to zero) the VIF test is low (equal to one).
} 
Among other controls we find that the log of household's income as well as education years have a positive and significant impact on self-declared life satisfaction. The same occurs for the number of rooms in the house, a variable which may be considered as a proxy of respondent's wealth, arguably better measured than self-reported income. Moreover, both living with a partner and being married increase life satisfaction relative to being single. Interestingly, larger families are associated with lower life satisfaction, presumably because of the lower share of gross total household income available for individuals living in households with many components. The number of grandchildren positively affects self-declared life satisfaction although the effect is not very robust to different specifications. As expected, health problems, captured by the objective health indices used, have a negative and significant impact on life satisfaction, while ageing seems to affect it positively net of health effects. ${ }^{17}$ The introduction of country dummies allows us to control for country fixed effects which may account for both country specific omitted variables affecting life satisfaction (i.e. climate, institutions, culture) and heterogeneity in life satisfaction scales (country bias) (see, among others, Clark et al., 2005).

As it is well known the dependent variable (self-reported life satisfaction) is ordinal, so that its estimation would require an ordered logit or probit rather than OLS. Even though cardinal estimation is shown not to outperform ordinal estimation in this context ${ }^{18}$, we re-estimate both the baseline and augmented model presented in (1) and (2) with an ordered probit approach. Results are presented in columns 5-8 of Table 3 and are substantially consistent with those obtained with OLS in terms of significance and coefficient sign.

Table A.1, in the Appendix, reports the marginal effects of the ordered probit model for the 010 life satisfaction dependent variable and also reports the marginal effects of the probit model where the dependent variable equals one if life satisfaction is above median. Sociability has a remarkable impact increasing by $10 \%$ the probability of declaring a level of life satisfaction equal to 10 and by $12 \%$ the probability of declaring a level of life satisfaction above median. Likewise individuals engaged in at least one social activity increase by $3 \%$ and $4 \%$ the probability of declaring a level of life satisfaction equal to 10 and a level of life satisfaction above median respectively.

\footnotetext{
${ }^{17}$ In our sample people are aged above 50. For this reason, the result may capture the ascending part of the Ushaped relationship between age and happiness (see among others Clark et al., 1996 and Frijters and Beatton, 2008).

18 See Ferrer-i-Carbonell and Frijters (2004) on this point.
} 
We have shown so far that other-regarding activities positively and significantly affect selfdeclared life satisfaction. Hence, hypothesis i) formulated in the previous session seems to be empirically confirmed. In order to check for the superiority of the augmented specification relative to the baseline (the second hypothesis), we compare the adjusted $\mathrm{R}^{2}$, AIC and BIC statistics across the estimated models. We find that the introduction of the additional regressors both in the OLS and ordered probit estimates delivers the highest values for $\mathrm{R}^{2}$ and the lowest ones for AIC and BIC, confirming the superior performance of the full specification relative to the baseline in terms of goodness of fits.

We want to check whether our results persist when we try to correct for measurement error in the dependent variable by considering different proxies of life satisfaction. We may reasonably assume that, when answering the standard life satisfaction question, individuals intuitively weight various life satisfaction sub-components (vitality, evaluation of past life, opportunities for the future, overall meaning of their own life, etc.). Since such averaging process is not simple, we may reasonably expect that the standard life satisfaction question has much more noise and measurement error than a latent factor which we extract using the answers to the above mentioned sub-components. ${ }^{19}$ Based on these considerations we use the ancillary life satisfaction question of the SHARE database. ${ }^{20}$ For each item answers are given on a 1-4 scale with an adjective (often, sometimes, rarely, never) being matched to any value. We use the ancillary question in three ways. In the first, we regress the overall life satisfaction score on the eleven subcomponents and use the predicted dependent variable as dependent variable of our base estimate. In the second we simply use the unweighted average of the subcomponents as dependent variable. In the third we extract the first principal

\footnotetext{
${ }^{19}$ A further advantage of the proposed approach is that subcomponent questions are formulated in the SHARE database on a 1-4 range with any of the four numbers being associated to an adjective whose meaning can be easily understood. On the contrary, no verbal correspondence exists for the numerical values of the standard 0 10 life satisfaction question.

20 The question contains the following 11 items: i) How often do you think your age prevents from doing the things you would like to do? ii) How often do you feel that what happens to you is out of control? iii) How often do you feel left out of things? iv) How often do you feel that you can do the things that you want to do? v) How often do you feel that family responsibilities prevent you from doing what you want to do? vi) How often do you feel that shortage of money stops you from doing the things that you want to do? vii) How often do you look forward to another day? viii) How often do you feel that your life has meaning? ix) How often on balance, do you look back to your life with a sense of happiness? x) How often do you feel full of energies these days? xi) How often do you fell that life is full of opportunities?
} 
component of the eleven subcomponents and use it as the dependent variable of our standard specification. ${ }^{21}$

As it is clear from Table A.2, reported in the Appendix, the goodness of fit of our estimates improves with the pseudo R-squared jumping from .18 to .33 under the best fit alternative. The difference in terms of BIC and AIC is also very strong (values are up to more than three times smaller with the alternative dependent variables). The significance of our sociability regressors is remarkably stable and therefore proves to be robust to the changes in the dependent variable.

\section{Social activities, motivations and social norms compliance.}

Econometric findings documented above identify a positive and significant nexus between various sociability measures and life satisfaction. Rationales for the observed findings include other-regarding motivations, self-regarding motivations and compliance to social norms. In order to discriminate among them we identify among sociability variables the two which are more related to altruistic behavior (voluntary/charity work, help to friends/neighbours). By looking at motivations for such behavior we isolate the two motivations which are more likely to be other-regarding (because I'm needed, to contribute to something useful) from the other ones (to meet friends, to earn money, to use skills or to keep fit). Our goal is to check whether the interaction between participation to at least one of the two social activities more related to altruistic behavior with at least one other-regarding motivation (because I'm needed and/or to contribute to something useful) is positively correlated with life satisfaction.

First of all, we split each of the six sociability variables into two variables, i.e. one in which individuals report at least one of the two other-regarding motivations and another in which they do not report such motivations. For the sake of clarity, in the first case, the activity variable is followed by the suffix "altruism", whereas in the second by the suffix "no altruism"; hence we have a total of 12 motivation-interacted activity variables. We test the new specification with two different dependent variables. The first is the standard cognitive measure of subjective wellbeing (life satisfaction), the second is an eudaimonic measure of life

\footnotetext{
21 The first principal component accounts for 37 percent of the variability. The Kaiser-Meyer-Olin measure of sampling adequacy (0.76) rejects the hypothesis that the variables have too little in common to make a principal component analysis valuable (Keiser and Rice, 1974).
} 
satisfaction represented by the consent given by survey respondents to the proposition "life is meaningful for me".

Results reported in Table 4 can be summarized as follows:

i) Other-regarding motivations on the two activities more related to altruistic behavior (voluntary/charity work and provided help to friends/neighbours) affect positively and significantly life satisfaction.

ii) The positive effect from the same two activities vanishes when such otherregarding motivations are absent.

iii) Participation to the other social activities (religious attendance, participation to sport or social organisations) in general positively affects life satisfaction with or without other regarding motivations.

iv) Caring for a sick/disabled adult with other-regarding motivations has negative and significant effects on the cognitive measure of subjective wellbeing (life satisfaction), while positive and significant effects on the eudaimonic measure of subjective wellbeing (life has meaning).

A first plausible interpretation for these findings is that individuals have heterogeneous preferences. Some of them have other regarding preferences which lead them to enjoy social activities more related to altruistic behavior (voluntary/charity work and help provided to friends/neighbours) but to suffer when another human being they are caring for is ill/disabled, deciding nonetheless to assist her/him since this choice is conferring meaning to their own life (eudaimonic wellbeing). In this case the negative empathetic effect produced by the relationship with another suffering individual is likely to be stronger than the life-enriching one of helping the sick/disabled and this might explain why the net effect produces a negative impact on life satisfaction.

Note however that this last evidence may also be interpreted in the sense of the existence of a social norm which tells us that the sick/disabled have to be helped. This would give meaning to life even though impacting negatively upon cognitive subjective wellbeing. Hence, it is not possible to discriminate between these two rationales based only on this evidence.

On the other side of our findings we have individuals who do not perform social activities or individuals who perform them without other-regarding motivations and, for this reason, do 
not particularly enjoy those activities more related to altruistic behavior (voluntary/charity work and provided help to family/friend).

As noted above, it is difficult to disentangle other-regarding preferences from social norms even though compliance to social norms does not necessarily increase life satisfaction. ${ }^{22} \mathrm{We}$ try to do so by proxying the local social norm with the average share of individuals performing other regarding activities (voluntary/charity work and/or helping family/friends in the corresponding NUTS2 area (Table 5, columns 3-4 and 7-8). We therefore re-estimate our model for the two subsamples of individuals living in regions where the average share of individuals performing other regarding activities is either above or below the sample median respectively. ${ }^{23}$ Our findings on the positive and significant effect of performing at least one other regarding activity with altruistic motivations on life satisfaction is unaltered in both cases. This indicates that our result is equally valid in regions where the social norm in performing such activities is high or low.

We also consider the hypothesis of strategic reasons behind voluntary/charity work and helping friends/neighbours, e.g. the desire to improve one's own social network or such activities intended as a form of apprenticeship which may increase future employment opportunities. Specifically, we restrict the sample to people outside the job market, i.e. retired individuals, in our sample. Results reported in Table 5 (columns 2 and 6) reveal that the effect of voluntary/charity work and/or helping friends/neighbours on life satisfaction is still significant although retired individuals record a higher coefficient on performing at least one other-regarding activity with other regarding motivations.

\section{Tackling endogeneity}

So far we have discussed of our results in terms of correlations. Taking causality seriously, we are aware that our estimates are not free of endogeneity. A reverse causal link between sociability and life satisfaction cannot, in fact, be ruled out (i.e. the enjoyment of high levels of life satisfaction may make individuals more willing to undertake social activities). In addition to it, when estimating the impact of social activities on life satisfaction, one might argue that

\footnotetext{
${ }^{22}$ What is generally expected is that noncompliance to a social norm produces a disutility, while compliance to social norm does not necessarily increases life satisfaction unless the norm is interiorised.

${ }^{23}$ In the median region of our sample $34 \%$ of respondents perform at least one other regarding activity (voluntary/charity work and helping family/friend)
} 
we are ignoring unobservable third omitted factors, correlated with both (i.e. social/relational attitudes), which lead to overestimating the true effect of the former on the latter. In order to tackle these problems, we present an instrumental variable approach (IV, hereon) in this section and we perform a sensitivity analysis in the next section (Imbens, 2003).

The first step for the IV estimation is the selection of the models to be instrumented. As a baseline model, we chose the one reported in the first column of Table 3. To account for possible endogeneity in the above-presented models concerning motivation and the type of activity, we replace the large number of variables suspected of endogeneity in Tables 3-5 with synthetic indicators and finally instrument them. We create two dummy variables equal to one if i) the individual has carried out voluntary/charity work and/or helped friends/neighbours (variable other reg activities), ii) the individual declared at least one of the two other regarding motivations (i.e. contribute to something useful or "because I am needed" - var. other reg mot). Finally we use the interaction term between activities and motivations mentioned above (var. other reg actmot).

Table 6a reports results from OLS estimates using these synthetic indicators. In the first column we look at the effect of at least one other-regarding activity on life satisfaction restricting the sample to people who carry out at least one social activity. In the second column, we exclude from the analysis people who do not carry out other regarding activities. In both cases, regression results confirm the positive and significant impact of otherregarding activities on life satisfaction with a larger magnitude when comparing individuals who do such activities vis-à-vis those who do not (column 2). In columns 3-4 we replace the activity dummy with the dummy capturing other regarding motivations (var. other reg mot) and, as in the previous case, we exclude those who do not carry out any social activity (column 3) and those who declare no other regarding motivations (column 4). In both cases, at least one other regarding motivation is associated with higher life satisfaction and the effect is larger when comparing those who report such motivations with those who do not carry out any activity (column 4). Finally, in the last three columns we examine the impact of the interaction between other regarding activities and motivations on life satisfaction, excluding alternatively those i) who do not carry out social activities (column 5), ii) who do not carry out other-regarding activities (column 6), and iii) who do not declare otherregarding motivations (column 7). In all of these cases, we find a significant and positive effect of the interaction between at least one other regarding activity and at least one other regarding motivation on life satisfaction. These findings mirror previous results on the added 
value that both other regarding activities and motivations bring to life satisfaction when interacted. ${ }^{24}$

The second step consists of instrumenting the baseline OLS model reported in Table 3 (column 1) as well as the models with all the synthetic indicators introduced above (Table 6a). We use internal instruments built using two versions of the endogenous variable, i.e. i) its average for the same region of the respondent, and ii) its average for the respondent's neighbouring region exploiting the NUTS2 nomenclature. In particular, our two stage approach can be summarized in the following equations:

$$
\begin{aligned}
& W_{i, r}=\gamma_{0}+\gamma_{1} \bar{W}_{r}+\gamma_{2} \bar{W}_{k, k \neq r}+\sum_{j=3}^{n} \gamma_{j} X_{i r j}+\varepsilon_{i r} \\
& \text { lifesat }_{i r}=\beta_{0}+\beta_{1} \hat{W}_{i r}+\sum_{j=2}^{n} \beta_{j} X_{i r j}+\eta_{i r}
\end{aligned}
$$

where $W_{i, r}$ is the endogenous variable (i.e. in our case at least one, other reg activities, other reg mot or other reg actmot) for individual $i$ in region $r$; $\bar{W}_{r}$, is the first instrumental variable and it is defined as the average of $W$ for region $r$ (i.e. the region of the respondent); $\bar{W}_{k, k \neq r}$ is the second instrumental variable and is the average of $W$ for region $k \neq r$ (i.e. a region different from that where the respondent is living); $X$ are the same socio-demographic controls described in the previous sections for individual $i$ in region $r ; \hat{W}_{i r}$ are the predicted values of $W_{i i}$ from equation 3a. To ensure instrument relevance, $\bar{W}_{k, k \neq r}$ is constructed by selecting the respondent's neighbouring region $k$; in case of multiple neighbours we use a weighted average of $\bar{W}_{k}$ for each of the $k$ neighbours, with the weights equal to the length of the shared border. ${ }^{25}$

We believe in the relevance of our instruments since it is reasonable to think of $\bar{W}_{r}$ and $\bar{W}_{k, k \neq r}$ as highly correlated with $W_{i r}$ - for instance, due to contagion, peer effects, social norms. We also believe in their validity, since it is plausible for $\bar{W}_{r}$ and $\bar{W}_{k, k \neq r}$ to affect life satisfaction only

\footnotetext{
${ }^{24}$ Ideally one would expect all the activity and motivation indicators (plus they interaction) jointly added as controls in a single regression. We opted to isolate the impact of these variables through sample restrictions because they turn out to be highly collinear and therefore would have affected the reliability of our results. Note, for instance, the correlation between other reg activities and other reg mot is 0.7532 .

25 See also Aslam and Corrado (2012) for the use of geographical aggregates as internal instruments.
} 
through $W_{i r}$ and not through other unobservable variables. ${ }^{26}$ In any case, the theoretical relevance and validity of our instruments is supported by ad-hoc tests run after all the IV estimations.

Results from the IV estimations are reported in Table $6 \mathrm{~b}$ and support all the previous findings. Importantly, all the models shown in Table $6 \mathrm{~b}$ pass the Hansen overidentification and Stock Yogo weak instrument tests, suggesting that our instruments are not weak (the F-statistic of the first stage is very high) and we cannot reject the null of overidentification validity (the pvalue of the Hansen test is always above the $0.07 \%$ threshold). ${ }^{27}$

\subsection{Sensitivity Analysis}

As outlined above, selection might bias our results if an unobservable trait determines both the involvement into social activities and life satisfaction. Unobservables of this kind can be, for instance, the ability of establishing social relations, personal friendliness, the degree of self-confidence and all other similar personality traits which may make the assumption of sociability exogeneity hard to support. For this reason, in addition to the previous IV estimations, we perform a robustness check of our results to the departure from the sociability-exogeneity assumption. One of the advantages of this approach with respect to IV is that in this case we don't rely on instrument validity and exogeneity assumptions which are usually debatable (even though in our case they are supported by empirical tests).

We implement Imbens (2003)'s sensitivity analysis which consists in modelling relaxations of unconfoundedness and evaluating if the assumptions necessary to determine a huge impact of a potential unobservable on the estimation of the average treatment effect (ATE) are realistic. Under this approach an unobserved covariate $U$ can determine a bias when highly correlated both with treatment assignment $T$ (in our case, the choice of implementing at least one social activity) and outcome $Y$ (in our case, life satisfaction). We model the possible channels through which $U$ influences $T$ and $Y$ leading to a bias of a fixed amount in the ATE estimation;

\footnotetext{
${ }^{26}$ Notice that both $\bar{W}_{r}$ and $\bar{W}_{k, k \neq r}$ are not significant when added as additional controls in the model presented in Table 3, col 1. Results of this regression is omitted for reason of space but available upon request.

${ }^{27}$ In the IV estimates the coefficients of interests are larger than those in the OLS benchmark. This maybe due (as in many IV findings with similar instruments) to the fact we lose some variability in the reduced form equation since we instrument a variable varying at the individual level with one varying at regional level. The significance of the main variables seems, however, not to be affected by this problem.
} 
we then use the observed $X$ to benchmark the plausibility of the existence of such an unobservable. ${ }^{28}$

The model we consider as the baseline is that reported in Table 3, column 3 in which the ATE (estimated under exogeneity) captures the impact of carrying out at least one activity (at least one activity) on life satisfaction. In Figure 3 we report the results from the general sensitivity analysis performed using the algorithm developed by Harada (2012). In panel A, the solid curve is the set of partial $\mathrm{R}^{2}$ for $\mathrm{U}$ that corresponds to an ATE which is the half of the baseline ATE; in panel B the solid curve is the set of partial $R^{2}$ for $U$ that corresponds to an ATE equal to 0.01 (i.e. no impact at all). Finally, in panel $C$ the solid curve is the set of partial $R^{2}$ for $U$ which corresponds to an ATE no longer significant at 95\% confidence level. The "+" signs are the partial $\mathrm{R}^{2}$ values for the $\mathrm{X}$ covariates of the baseline model.

We can interpret the plots of Figure 3a as representing each of the observed controls according to their power to explain variation in both $\mathrm{T}$ (at least one activity) and $\mathrm{Y}$ (in this case, life satisfaction). In the vertical axis we report the marginal increase in the $\mathrm{R}^{2}$ from adding the covariate to a regression of life satisfaction on all other covariates; in the horizontal axis we show the marginal influence of the covariate to the variation in $\mathrm{T}$. The curve can be interpreted as a threshold, beyond which $U$ is so influential to reduce the baseline ATE by half (panel A), completely (panel B) or to make it statistically insignificant (panel C).

Notice that, in all the plots, the observed covariates explain little variation in either $\mathrm{Y}$ or $\mathrm{T}$ and lie below the curve of $U$. This implies that any unobserved covariate that would be so correlated with $\mathrm{T}$ and $\mathrm{Y}$ to change the magnitude and significance of our baseline ATE would have to be much more important than all the $\mathrm{X}$ covariates, including gender, income, schooling years, household size, and age which - as outlined before - are highly correlated with life satisfaction. Hence, the main result from this analysis is that the ATE of carrying out at least one social activity on life satisfaction estimated under the assumption of exogeneity is robust to departures from it.

We run the sensitivity analysis also using alternatively as T variable the interaction between at least one other regarding activity and at least other regarding motivation (i.e., other reg actmot) for the specifications reported in columns 5-7 of Table 6a. Unobservables correlated

\footnotetext{
${ }^{28}$ See Rosenbaum and Rubin (1983) and Imbens (2003) for further details on this method. See Blattman and Annan (2010) for an application of it.
} 
with both other regarding motivations and activities as well as with life satisfaction are likely to bias our estimates. Results are the same as for at least one activity (see Panels A-I of Figure $3 b)$, confirming that the ATE of the overlap between other regarding activities and motivations on life satisfaction is robust when we relax the unconfoundedness assumption.

\section{Conclusions}

In this paper we provide an empirical analysis on social activities and their motivations. We find that social activities are significantly and positively correlated to cognitive measures of subjective wellbeing (life satisfaction). As it is well known there are at least four interpretations for such evidence. Other regarding activities may be performed for compliance to social norms or for the existence of self-regarding or other-regarding preferences in utility functions. Alternatively, the observed correlation may be explained by endogeneity or by an inverse causality nexus by which satisfaction with life brings individuals to behave more socially.

What we try to document in this paper is that, even though there is not just one explanation, the hypothesis that individuals with other regarding preferences increase their satisfaction with life by performing other regarding activities with other regarding motivations is not rejected by the data. The result is supported in standard OLS and ordered probit estimates, significant in IV estimates, robust to measurement error in the dependent variables and to relaxations of the exogeneity assumption.

The implications of our finding in terms of behavioral economics are relevant and tell us that we do not have to modify our theoretical apparatus but we need to represent individual preferences in a more realistic way. However this does not mean that the problem of misrepresentation is not serious. In fact, this limit has serious consequences on the fertility of social and economic relationships since purely self-regarding individuals tend to create less value for them and for the society in social dilemmas (such as those modeled in prisoner's dilemma, trust game and traveller's game).

Our empirical findings leave two questions open to further empirical research. First, we find evidence of heterogeneous motivations and we document that the impact of other regarding activities is conditional to the type of motivation: this suggests the existence of multiple equilibria with some people performing such activities with other regarding motivations and 
enjoying them and other people performing the same activities without other regarding motivations and not enjoying them. The question is therefore why the second group of people cannot access the virtuous circle of the first group.

Second, an original feature of our work is the focus on European individuals aged above 50. Future research will tell whether the same findings are cultural and age specific or do they apply more universally to other countries and age cohorts. 


\section{References}

Andreoni J. (1989). Giving with Impure Altruism: Applications to Charity and Ricardian Equivalence. Journal of Political Economy, 97, pp. 1447-58.

Andreoni, J. (1990). Impure Altruism and Donations to Public Goods: A Theory of Warm-Glow Giving. Economic Journal 100, 401, pp. 464-477.

Andreoni, J. \& B. Douglas Bernheim (2009). Social Image and the 50-50 Norm: A Theoretical and Experimental Analysis of Audience Effects, Econometrica, 77(5), September, 16071636.

Andreoni, J. and Miller, J., (2002). Giving According to GARP: An Experimental Test of the Rationality of Altruism, Econometrica, 70(2), pp. 737-753.

Aslam, A. \& L. Corrado (2012). The Geography of Well-Being, The Journal of Economic Geography, Volume 12, Issue 3, pp. 627-649.

Bartolini, S. Bilancini, E. \& Sarracino, F. (2009). Sociability Predicts Happiness: World-Wide Evidence from Time Series, Department of Economics University of Siena 579, Department of Economics, University of Siena.

Bartolini, S., Bilancini, E., \& Sarracino, F. (2012). Predicting the Trend of Well-Being in Germany: How Much Do Comparisons, Adaptation and Sociability Matter? Social Indicators Research, 1-23.

Becchetti L. (2011a). Beyond Homo Economicus, AICCON working paper n.97

Becchetti, L. \& Savastano, S. (2009). The Money-Happiness Relationship in Transition Countries: Evidence from Albania, Aiccon working paper.

Becchetti, L., Corrado, L., Samà, L. (2012). Inside the Life Satisfaction Blackbox, AICCON Working Papers 116-2012.

Becchetti, L., Degli Antoni, G., Ottone, S. \& Solferino, N. (2011c). Spectators versus Stakeholders with or without Veil of Ignorance: the Difference it Makes for Justice and Chosen Distribution Criteria, Econometica Working paper 31.

Becchetti, L., Giachin Ricca, E. \& Pelloni, A. (2011b), The 60es Turnaround as a Test on the Causal Relationship between Sociability and Happiness. Social Indicators Research, forth.

Becchetti, L., Pelloni, A. \& Rossetti, F. (2008). Relational Goods, Sociability, and Happiness, Kyklos, 61 (3), pp. 343-363.

Becker, T, Carter, M. \& Jörg Naeve (2005). Experts Playing the Traveler's Dilemma, Diskussionspapiere aus dem Institut für Volkswirtschaftslehre der Universität Hohenheim 252/2005, Department of Economics, University of Hohenheim, Germany.

Belot, M., V. Bhaskar, J. \& Van de Ven, G. (2010). Social Preferences in the Public Arena: Evidence from a Prisoner's Dilemma Game on a TV Show, mimeo

Ben-Ner, A. \& L. Putterman (2010). Trusting, Trustworthiness, and CSR: Some Experiments and Implications in L. Sacconi, M. Blair, R.E. Freeman and A.Vercelli (eds.) Corporate Social Responsibility and Corporate Governance: The Contribution of Economic Theory and Related Disciplines, Palgrave Macmillan, Basingstoke.

Berg, J. Dickhaut, J. \& McCabe K. (1995), Trust, Reciprocity and Social History, Games and Economic Behaviour, 10, pp. 122-142. 
Bilancini, E. \& D'Alessandro, S. (2011). Long-run Welfare under Externalities in Consumption, Leisure, and Production: $A$ Case for Happy Degrowth vs. Unhappy Growth," Center for Economic Research (RECent) 072, University of Modena and Reggio Emilia, Dept. of Economics.

Binmore, K. . \& Shaked, A. (2010), Experimental Economics:where next ? Rejoinder, Journal of Economic Behavior \& Organization, 73, 120-121

Blattman, C. \& Annan, A. J. (2010). The Consequences of Child Soldiering, Review of Economics and Statistics, 92, pp. 882-98.

Broberg, T., Ellingsen, T. \& Johannesson M. (2007). Is Generosity Involuntary? Economics Letters, 94(1), pp. 32-37.

Camerer, C. (2003). Behavioral Game Theory. Experiments in Strategic Interaction, Princeton, Princeton University Press.

Camerer, C. F. \& Thaler, R. H. (1995). "Ultimatums, Dictators and Manners", Journal of Economic Perspectives, 9, pp. 209-19.

Cameron, A. C. \& Trivedi, P. K. (2005). Microeconometrics: Methods and Applications, Cambridge University Press.

Carson, R. T., Flores, N. E. \& Meade, N. F. (2001), Contingent Valuation: Controversies and Evidence, Environmental and Resource Economics, 19, pp. 173-210.

Christelis, D., 2011. "Imputation of Missing Data in Waves 1 and 2 of SHARE," CSEF Working Papers 278, Centre for Studies in Economics and Finance

Clark, A. \& Lelkes, O. (2009). Let Us Pray: Religious Interactions In Life Satisfaction. Paris School of Economics, Working Paper 2009-01.

Clark, A., Etilé, F., Postel-Vinay, F., Senik, C. \& Van der Straeten, K. (2005). Heterogeneity in Reported Well-Being: Evidence from Twelve European Countries, Economic Journal, 115, pp.C118-C132.

Clark, A., Oswald, A. \& Warr, P. (1996). Is Job Satisfaction U-shaped in Age, Journal of Occupational and Organizational Psychology, 69, pp.57-81.

Dana, J., Cain, D.M., \& Dawes, R.M. (2006). What You Don't Know Won't Hurt Me: Costly but Quiet Exit in Dictator Games, Organizational Behavior and Human Decision Processes, 100, pp. 193-201.

Engel, C. (2010), Dictator Games: A Meta Study. MPI Collective Goods Preprint No. 2010/07

Fehr, E., \& Gächter, S. (2000). Cooperation and Punishment in Public Goods Experiments, American Economic Review, 90, pp. 980-994.

Fehr, E., Kirchler, E., Weichbold, A. \& Gächter, S. (1998). When Social Forces Overpower Competition: Gift Exchange in Experimental Labor Markets, Journal of Labor Economics, 16, pp. 324-351.

Fehr, E., Kirchsteiger, G. \& Riedl, A. (1993). Does Fairness Prevent Market Clearing? An Experimental Investigation, Quarterly Journal of Economics, 108, pp. 437-459.

Fehr, E., (2009). On The Economics and Biology of Trust, Journal of the European Economic Association, MIT Press, vol. 7(2-3), pages 235-266, 04-05. 
Ferrer-i-Carbonell, A. \& Frijters, P. (2004): How Important is Methodology for the Estimates of the Determinants of Happiness? The Economic Journal, 114. pp. 641-659.

Fischbacher, U., S. Gächter \& Fehr, E. (2001). Are People Conditionally Cooperative? Evidence from a Public Goods Experiment, Economics Letters, 71: 397-404

Frey, B. S. \& Stutzer, A. (2000). Happiness, Economy and Institutions. The Economic Journal, 110, pp. 918-938.

Frey, B. S. and Stutzer, A. (2005) Beyond Outcomes: Measuring Procedural Utility. Oxford Economic Papers, Vol. 57, No. 1, pp. 90-111.

Frijters, P. \& Beatton, T. (2008): The Mystery of the U-shaped Relationship between Happiness and Age. NCER Working Paper Series 26, National Centre for Econometric Research.

Goeree, J. K., Holt, C. A. \& Laury, S. K. (2002). Private Costs and Public Benefits: Unraveling the Effects of Altruism and Noisy Behavior, Journal of Public Economics, 83(2), pp. 255-76.

Güth, W., R. Schmittberger, \& B.Schwarze, (1982). An Experimental Analysis of Ultimatum Bargaining, Journal of Economic Behavior and Organization, 3, pp. 367-88.

Harada, M. (2012) Generalized Sensitivity Analysis, mimeo, University of Chicago.

Harbaugh, W.T. (1998). What Do Donations Buy? A Model of Philanthropy Based on Prestige and Warm Glow, Journal of Public Economics, 67, pp. 269-84.

Imbens, Guido W. (2003). Sensitivity to Exogeneity Assumptions in Program Evaluation. American Economic Review, 93(2), pp. 126-132.

Kaiser, H. \&. Rice, J. (1974). Little Jiffy, Mark IV, Journal of Educational and Psychological Measurement, 34, 111-117.

Konow J. (2010). Mixed Feelings: Theories of and Evidence on Giving, Journal of Public Economics , 94(3-4), pp. 279-297.

Leiderman, L. \& Blejer, M. I. (1988), Modeling and Testing Ricardian Equivalence: A Survey, IMF Staff Papers, 35(1), pp. 1-35.

List, J. A. (2007). On the Interpretation of Giving in Dictator Games, Journal of Political Economy, 115(3), pp. 482-493.

Marquardt D W. (1970). Generalized Inverses, Ridge Regression, Biased Linear Estimation, and Nonlinear Estimation, Technometrics, 12, 591-612.

Meier, S. \& Stutzer, A. (2008). Is Volunteering Rewarding in Itself?, Economica, London School of Economics and Political Science, 75(297), pp. 39-59.

Nielsen (2012). The Global Socially Conscious Consumer, accessed at http://www.nielsen.com/us/en/insights/reports-downloads/2012/the-global--sociallyconscious-consumer.html, The Nielsen Company, 30th July 2011.

Putnam, R. D. (2000). Bowling Alone: The Collapse and Revival of American Community. New York: Simon \& Schuster.

Ribar, D. C. \& Wilhelm, M. O. (2002). Altruistic and Joy-of-Giving Motivations in Charitable Behavior, Journal of Political Economy, 110, pp. 425-57.

Rosenbaum, P. \& Rubin, D. (1983). Assessing Sensitivity to an Unobserved Binary Covariate in an Observational Study with Binary Outcome. Journal of the Royal Statistical Society, Series $B, 45(2)$, pp. 212-18. 
Ryff, C.D. \& Singer, B.H. (2006). Know Thyself and Become What You Are: A Eudaimonic Approach to Psychological Well-Being. Journal of Happiness Studies, 9, 13-39.

Salamon, L. M., Wojciech Sokolowski and Associates (2004). Global civil society: Dimensions of the Nonprofit Sector. Bloomfield, US, Kumarian Press.

Sonnemans, J., Schram, A. \& Offerman T. (1999). Strategic Behavior in Public Good Games When Partners Drift Apart, Economics Letters, 62, pp. 35-41.

Van Buuren S, Brand JPL, Groothuis-Oudshoorn CGM, Rubin DB (2006). Fully Conditional Specification in Multivariate Imputation, Journal of Statistical Computation and Simulation, 76(12), 1049-1064. 


\section{Table 1 - Variable Legend}

\begin{tabular}{|c|c|}
\hline VARIABLE & DESCRIPTION \\
\hline Female & Dummy var $=1$ if respondent is female; $=0$ otherwise. \\
\hline Log income & $\begin{array}{l}\text { Log of household total gross income. Its value is equal to the sum over all household members of the individual-level values of: annual net income from employment and self-employment (in the previous year); Annual } \\
\text { public old age/early or pre-retirement/disability pension (or sickness benefits); Annual public unemployment benefit or insurance, public survivor pension from partner; Annual war pension, private (occupational) old } \\
\text { age/early retirement/disability pension, private (occupational) survivor pension from partner's job, public old age supplementary pension/public old age/public disability second pension, secondary public survivor pension } \\
\text { from spouse or partner, occupational old age pension from a second and third job; Annual public and private long-term insurance payments; Annual life insurance payment, private annuity or private personal pension, } \\
\text { private health insurance payment, alimony, payments from charities received; Income from rent. Values of the following household level variables are added: Annual other hhd members' net income; Annual other hhd } \\
\text { members' net income from other sources; Household bank accounts, government and corporate bonds, stocks/shares; mutual funds. }\end{array}$ \\
\hline Education years & Years the respondent has been in full time education \\
\hline
\end{tabular}

Household size

Age class

Number child

Hrooms

Big city

Suburbs

Suburbs

Large town

Small town

Rural area

Longtermill

No limited activities

Numb illnesses

Lifesat

Age no prevent

No out control

No fel left out

Fred. choice

No fam.responsibility

No lack money

Life meaningful members net income from other sources; Household
Years the respondent has been in full time education

Household size.

Respondent's age class: $=1$ age class if respondent's age $<55 ;=2$ if resp.'s age=[55,59]; =3 if resp.'s age=[60,64]; =4 if resp.'s age=[64,69]; $=5$ if resp.'s age =[69,74]; $=6$ if resp.'s age =[74,79]; = 7 if age $>79$.

Dummy var $=1$ if respondent lives as a single.

Respondent's numer of children (imputed as in Christelis, 2011).

Number of rooms in the main residence (imputed as in Christelis, 2011).

Dummy var=1 if respondent lives in a big city (imputed as in Christelis, 2011).

Dummy var=1 if respondent lives in suburbs or outskirts of a big city (imputed as in Christelis, 2011).

Dummy var=1 if respondent lives in a large town (imputed as in Christelis, 2011).

Dummy var=1 if respondent lives in a small town (imputed as in Christelis, 2011).

Dummy var=1 if respondent lives in a rural area or village (imputed as in Christelis, 2011).

Dummy var $=1$ if respondent declares any long-term health problems, illness, disability or infirmity. Survey question: "Some people suffer from chronic or long-term health problems. By long-term we mean it has troubled you over a period of time or is likely to affect you over a period of time. Do you have any long-term health problems, illness, disability or infirmity?".

Dummy var=1 if respondent has not been limited because of a health problem in activities people usally do. Survey question: "For the past six months at least, to what extent have you been limited because of a health problem in activities people usually do?".

It is the sum of illnesses the respondent is currently being treated for or bothered (A heart attack including myocardial infarction or coronary thrombosis or any other heart problem including congestive heart failure; High blood pressure or hypertension; High blood cholesterol; A stroke or cerebral vascular disease; Diabetes or high blood sugar; Chronic lung disease such as chronic bronchitis or emphysema; Asthma; Arthritis, including osteoarthritis, or rheumatism; Osteoporosis; Cancer or malignant tumour, including leukaemia or lymphoma, but excluding minor skin cancer; Stomach or duodenal ulcer, peptic ulcer; Parkinson disease; Cataracts; Hip fracture or femoral fracture; Alzheimer's disease, dementia, organic brain syndrome, senility or any other serious memory impairment; Benign tumor).

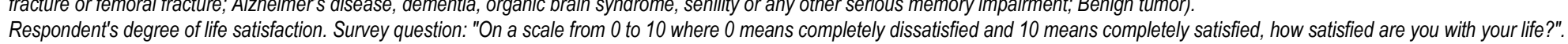

Respondent's degree of statements that have used to describe their lives or how they feel. Survey question: "How often do you think your age prevents from doing the things you would like to do ?". For each item answers are given on a $1-4$ scale where an adjective (often, sometimes, rarely, never) is matched to any value.

Respondent's degree of statements that have used to describe their lives or how they feel. Survey question: "How often do you feel that what happens to you is out of control?". For each item answers are given on a 1-4 scale where an adjective (often, sometimes, rarely, never) is matched to any value.

Respondent's degree of statements that have used to describe their lives or how they feel. Survey question: "How often do you feel left out of things ?". For each item answers are given on a 1-4 scale where an adjective (often, sometimes, rarely, never) is matched to any value.

Respondent's degree of statements that have used to describe their lives or how they feel. Survey question: "How often do you feel that you can do the things that you want to do?" For each item answers are given on a 1 4 scale where an adjective (often, sometimes, rarely, never) is matched to any value.

Respondent's degree of statements that have used to describe their lives or how they feel. Survey question: How often do you feel that family responsibilities prevent you from doing what you want to do? For each item answers are given on a 1-4 scale where an adjective often, sometimes, rarely, never) is matched to any value.

Respondent's degree of statements that have used to describe their lives or how they feel. Survey question: "How often do you feel that shortage of money stops you from doing the things that you want to do?". For each Respondent's degree of statements that have used to describe their lives or how they feel. Survey question: "How
item answers are given on a $1-4$ scale where an adjective (often, sometimes, rarely, never) is matched to any value.

Respondent's degree of statements that have used to describe their lives or how they feel. Survey question: "How often do you feel that your life has meaning ?". For each item answers are given on a 1-4 scale where an Respondent's degree of statements that have used to describe their liv
adjective (often, sometimes, rarely, never) is matched to any value. 


\section{Past good}

Vitality

Opportunities

Voluntary

Rel. attendance

Pol. participation

Help to friends

Cared for sick

Sport social

Voluntary altruism

Rel. attendance altruism

Pol. Participation altruism

Help to friends altruism

Cared for sick altruism

Sport social altruism

Voluntary no altruism

Rel. attendance no altruism

Pol. participation no altruism

Help to friends no altruism

Cared for sick no altruism

Sport social no altruism

At least one activity

Sociability

Other reg activities

Other reg motivation

Other reg actmot
Respondent's degree of statements that have used to describe their lives or how they feel. Survey question: "How often on balance, do you look back to your life with a sense of happiness?". For each item

answers are given on a 1-4 scale where an adjective (often, sometimes, rarely, never) is matched to any value.

Respondent's degree of statements that have used to describe their lives or how they feel. Survey question: "How often do you feel full of energies these days?". For each item answers are given on a 1-4 scale where an adjective (often, sometimes, rarely, never) is matched to any value.

Respondent's degree of statements that have used to describe their lives or how they feel. Survey question: "How often do you fell that life is full of opportunities?". For each item answers are given on a 1-4 scale where an adjective (often, sometimes, rarely, never) is matched to any value.

Dummy var $=1$ if respondent has done voluntary or charity work in the last month.

Dummy var=1 if respondent has taken part in activities of a religious organization (church, synagogue, mosque etc.) in the last month.

Dummy var 1 if respondent has taken part in a political or community-related organization in the last month.

Dummy var=1 if respondent has provided help to friends or neighbors in the last month

Dummy var 1 if respondent has cared for a sick or disabled adult in the last month.

Dummy var 1 if respondent has gone to a sport, social or other kind of club in the last month.

Dummy var=1 if respondent has done voluntary or charity work in the last month and reports at least one other regarding motivation (because l'm needed, to contribute to something useful).

Dummy var= 1 if respondent has taken part in activities of a religious organization and reports at least one other regarding motivation (because l'm needed and/or to contribute to something useful).

Dummy var=1 if respondent has in a political or community-related organization and reports at least one other regarding motivation (because l'm needed and/or to contribute to something useful).

Dummy var=1 if respondent has provided help to friends or neighbors in the last month and reports at least one other regarding motivation (because l'm needed and/or to contribute to something useful).

Dummy var=1 if respondent has cared for a sick or disabled adult in the last month and reports at least one other regarding motivation (because l'm needed and/or to contribute to something useful).

Dummy var=1 if respondent has has gone to a sport, social or other kind of club in the last month and reports at least one other regarding motivation (because l'm needed and/or to contribute to something useful).

Dummy var=1 if respondent has done voluntary or charity work in the last month without at least one other regarding motivation (because l'm needed and/or to contribute to something usefull).

Dummy var= 1 if respondent has taken part in activities of a religious organization (without at least one other regarding motivation (because l'm needed and/or to contribute to something useful).

Dummy var=1 if respondent has in a political or community-related organization without at least one other regarding motivation (because l'm needed and/or to contribute to something useful).

Dummy var= 1 if respondent has provided help to friends or neighbors in the last month without at least one other regarding motivation (because I'm needed and/or to contribute to something useful).

Dummy var=1 if respondent has cared for a sick or disabled adult in the last month without at least one other regarding motivation (because l'm needed and/or to contribute to something useful).

Dummy var=1 if respondent has has gone to a sport, social or other kind of club in the last month without at least one other regarding motivation (because l'm needed and/or to contribute to something useful).

Dummy var=1 if respondent has carried out at least one social activity (i.e. voluntary, rel. attendance, pol. participation, help to friends, cared for sick or spor/social).

Sum of all the social activities carried out by the respondent stantardized by the sum of activities (equal to 6).

Dummy var= 1 if the respondent has carried out voluntary/charity work and/or helped friends/neighbours

Dummy var 1 if the respondent reports at least one of the two other regarding motivations (contribute to something useful or because I am needed).

Dummy var= 1 if the respondents carried out other reg activities with other reg motivation 
Table 2a. Descriptive Statistics (full sample)

\begin{tabular}{|c|c|c|c|c|c|}
\hline variable & mean & $\max$ & $\min$ & sd & $\mathbf{N}$ \\
\hline lifesat & 7.56 & 10 & 0 & 1.782 & 33518 \\
\hline female & 0.50 & 1 & 0 & 0.500 & 34415 \\
\hline logincome & 10.60 & 15.336 & 2.996 & 1.398 & 32991 \\
\hline eduyears & 10.54 & 25 & 0 & 4.279 & 33838 \\
\hline household size & 2.25 & 14 & 1 & 1.085 & 34415 \\
\hline age & 65.40 & 105 & 1 & 10.159 & 34406 \\
\hline single & 0.42 & 1 & 0 & 0.493 & 44190 \\
\hline widowed & 0.15 & 1 & 0 & 0.355 & 34389 \\
\hline divorced & 0.06 & 1 & 0 & 0.245 & 34389 \\
\hline separated & 0.01 & 1 & 0 & 0.101 & 44190 \\
\hline registered partnership & 0.01 & 1 & 0 & 0.119 & 34389 \\
\hline married & 0.71 & 1 & 0 & 0.454 & 34389 \\
\hline n. of children & 2.19 & 16 & 0 & 1.367 & 33280 \\
\hline n. of grand children & 2.60 & 22 & 0 & 3.049 & 33280 \\
\hline hrooms & 3.91 & 25 & 0 & 1.639 & 33280 \\
\hline bigcity & 0.14 & 1 & 0 & 0.348 & 33280 \\
\hline suburbs & 0.16 & 1 & 0 & 0.361 & 33280 \\
\hline largetown & 0.19 & 1 & 0 & 0.393 & 33280 \\
\hline smalltown & 0.23 & 1 & 0 & 0.418 & 33280 \\
\hline rural & 0.28 & 1 & 0 & 0.447 & 33280 \\
\hline sociability & 0.12 & 0 & 1 & 0.166 & 33620 \\
\hline at least one activity & 0.46 & 1 & 0 & 0.499 & 33620 \\
\hline voluntary & 0.12 & 1 & 0 & 0.330 & 33620 \\
\hline religion attendance & 0.12 & 1 & 0 & 0.324 & 33620 \\
\hline political participation & 0.04 & 1 & 0 & 0.203 & 33620 \\
\hline help to friends & 0.18 & 1 & 0 & 0.380 & 33620 \\
\hline cared for sick & 0.07 & 1 & 0 & 0.263 & 33620 \\
\hline sport/social clubs & 0.20 & 1 & 0 & 0.399 & 33620 \\
\hline voluntary altruism & 0.08 & 1 & 0 & 0.280 & 44190 \\
\hline cared for sick altruism & 0.05 & 1 & 0 & 0.223 & 44190 \\
\hline help to friends altruism & 0.12 & 1 & 0 & 0.327 & 44190 \\
\hline sport/social clubs altruism & 0.13 & 1 & 0 & 0.336 & 44190 \\
\hline religion attendance altruism & 0.07 & 1 & 0 & 0.257 & 44190 \\
\hline political participation altruism & 0.02 & 1 & 0 & 0.142 & 44190 \\
\hline voluntary no altruism & 0.01 & 1 & 0 & 0.103 & 33620 \\
\hline cared for sick no altruism & 0.01 & 1 & 0 & 0.071 & 33620 \\
\hline help to friends no altruism & 0.01 & 1 & 0 & 0.119 & 33620 \\
\hline sport/social clubs no altruism & 0.02 & 1 & 0 & 0.161 & 33620 \\
\hline religion attendance no altruism & 0.02 & 1 & 0 & 0.156 & 33620 \\
\hline political participation no altruism & 0.01 & 1 & 0 & 0.125 & 33620 \\
\hline other reg activities & 0.25 & 1 & 0 & 0.435 & 33620 \\
\hline other reg motivation & 0.32 & 1 & 0 & 0.469 & 33620 \\
\hline other reg actmot & 0.23 & 1 & 0 & 0.425 & 33620 \\
\hline age no prevent & 2.64 & 4 & 1 & 1.035 & 33610 \\
\hline no out control & 2.84 & 4 & 1 & 0.956 & 33444 \\
\hline no feel left out & 3.05 & 4 & 1 & 0.959 & 33506 \\
\hline fred choice & 3.23 & 4 & 1 & 0.885 & 33563 \\
\hline no fam resp & 3.04 & 4 & 1 & 0.974 & 33564 \\
\hline no lack money & 2.56 & 4 & 1 & 1.104 & 33573 \\
\hline life meanining & 3.56 & 4 & 1 & 0.719 & 33368 \\
\hline past good & 3.39 & 4 & 1 & 0.757 & 33275 \\
\hline vitality & 3.15 & 4 & 1 & 0.858 & 33591 \\
\hline opportunities & 3.10 & 4 & 1 & 0.871 & 33392 \\
\hline future good & 3.08 & 4 & 1 & 0.878 & 33181 \\
\hline long term illness & 0.47 & 1 & 0 & 0.499 & 34292 \\
\hline limited activities & 0.43 & 1 & 0 & 0.495 & 34293 \\
\hline num. illnesses & 1.09 & 13 & 0 & 1.396 & 44190 \\
\hline
\end{tabular}

Altruism variables: social activities performed with at least one other regarding motivation (because l'm needed, to contribute to something useful). No altruism variables: social activities performed without at least one other regarding motivation (because l'm needed, to contribute to something useful). 
Table 2b. Descriptive Statistics (full sample)

\begin{tabular}{cccccccccc}
\hline & lifesat & at_least_one & sociability & voluntary & religion att. & political part. & help to family & cared for sick & sport/social \\
\hline Denmark & 8.50 & 0.67 & 0.18 & 0.22 & 0.08 & 0.05 & 0.28 & 0.06 & 0.41 \\
Switzerland & 8.37 & 0.61 & 0.18 & 0.18 & 0.15 & 0.09 & 0.20 & 0.11 & 0.34 \\
Sweden & 8.31 & 0.68 & 0.19 & 0.21 & 0.12 & 0.05 & 0.40 & 0.10 & 0.27 \\
Ireland & 8.18 & 0.64 & 0.20 & 0.16 & 0.34 & 0.06 & 0.24 & 0.12 & 0.28 \\
Netherlands & 7.93 & 0.63 & 0.19 & 0.27 & 0.13 & 0.04 & 0.24 & 0.11 & 0.33 \\
Germany & 7.65 & 0.48 & 0.13 & 0.14 & 0.10 & 0.04 & 0.16 & 0.09 & 0.26 \\
Belgium & 7.63 & 0.55 & 0.15 & 0.17 & 0.09 & 0.08 & 0.24 & 0.10 & 0.23 \\
Austria & 7.63 & 0.41 & 0.11 & 0.09 & 0.09 & 0.04 & 0.17 & 0.08 & 0.18 \\
France & 7.32 & 0.49 & 0.14 & 0.16 & 0.08 & 0.05 & 0.21 & 0.09 & 0.23 \\
Spain & 7.27 & 0.21 & 0.04 & 0.02 & 0.09 & 0.01 & 0.03 & 0.03 & 0.07 \\
Italy & 7.20 & 0.27 & 0.06 & 0.08 & 0.07 & 0.02 & 0.07 & 0.04 & 0.08 \\
Greece & 7.06 & 0.42 & 0.09 & 0.02 & 0.28 & 0.04 & 0.07 & 0.05 & 0.06 \\
Czechia & 7.03 & 0.33 & 0.07 & 0.03 & 0.05 & 0.03 & 0.13 & 0.06 & 0.13 \\
Poland & 6.55 & 0.20 & 0.04 & 0.02 & 0.10 & 0.02 & 0.05 & 0.04 & 0.02 \\
\hline \hline
\end{tabular}

Table 3. Determinants of life satisfaction

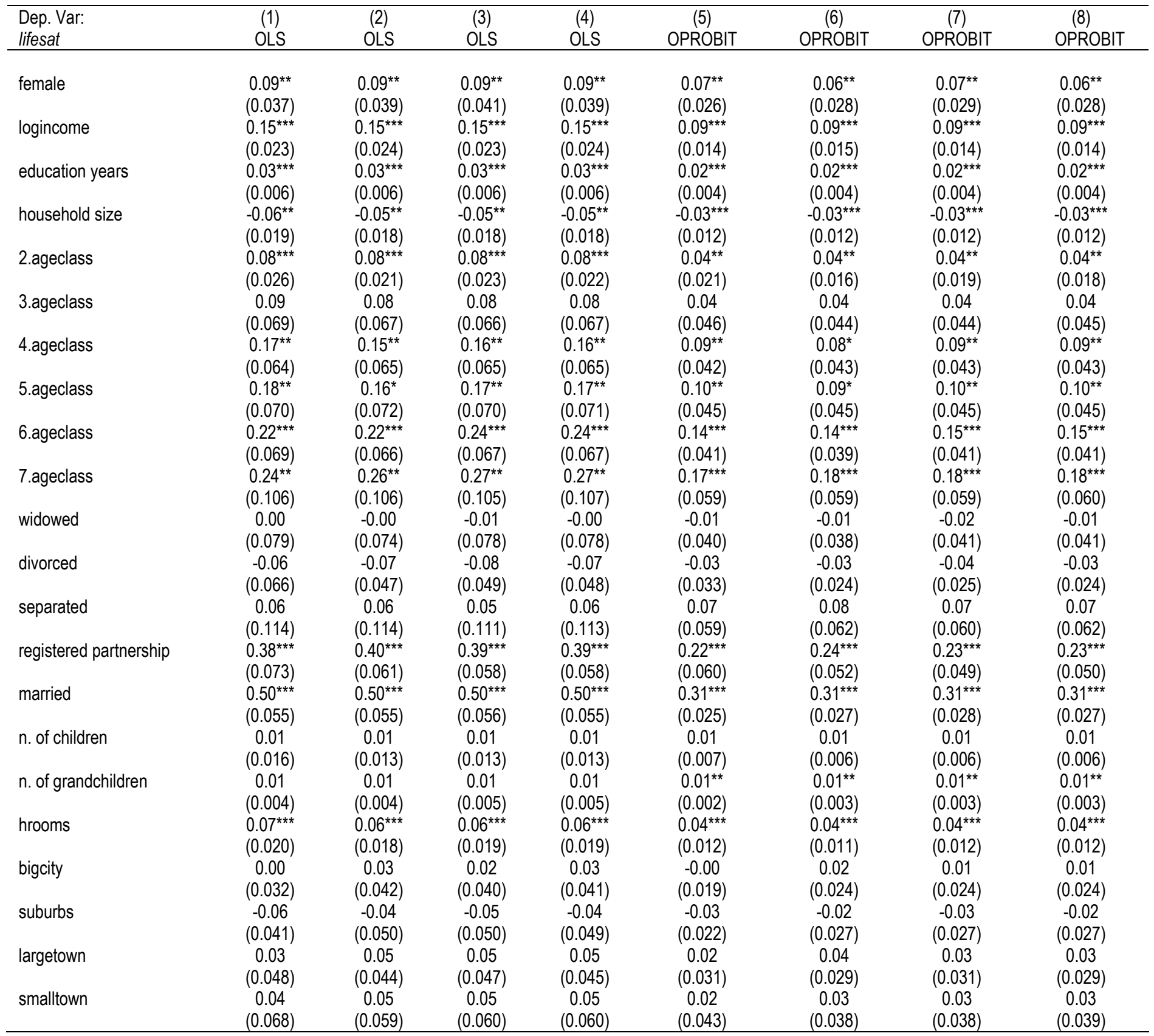




\section{Cont.}

\begin{tabular}{|c|c|c|c|c|c|c|c|c|}
\hline \multirow[t]{2}{*}{ long term illness } & $-0.24^{\star * *}$ & $-0.24^{\star \star \star}$ & $-0.24^{\star * *}$ & $-0.25^{\star \star *}$ & $-0.16^{\star \star *}$ & $-0.16^{* * *}$ & $-0.16^{\star \star *}$ & $-0.16^{\star \star *}$ \\
\hline & $(0.024)$ & $(0.023)$ & $(0.024)$ & $(0.024)$ & $(0.016)$ & $(0.015)$ & $(0.015)$ & $(0.015)$ \\
\hline \multirow[t]{2}{*}{ limited activities } & $-0.61^{* * *}$ & $-0.59^{\star * \star}$ & $-0.58^{* * *}$ & $-0.59^{* * *}$ & $-0.36^{* * *}$ & $-0.35^{\star * *}$ & $-0.35^{* * *}$ & $-0.35^{* * *}$ \\
\hline & $(0.053)$ & $(0.057)$ & $(0.058)$ & $(0.058)$ & $(0.031)$ & $(0.033)$ & $(0.033)$ & $(0.033)$ \\
\hline \multirow[t]{2}{*}{ numb. illnesses } & $-0.13^{* * *}$ & $-0.13^{* * *}$ & $-0.13^{\star \star \star}$ & $-0.13^{* * *}$ & $-0.07^{* \star *}$ & $-0.08^{* * *}$ & $-0.08^{* * *}$ & $-0.08^{\star * *}$ \\
\hline & $(0.014)$ & $(0.016)$ & $(0.016)$ & $(0.016)$ & $(0.009)$ & $(0.010)$ & $(0.010)$ & $(0.010)$ \\
\hline \multirow[t]{2}{*}{ Austria } & $0.21^{\star \star \star}$ & $0.19^{\star \star \star}$ & $0.20^{\star \star *}$ & $0.19^{\star \star \star}$ & $0.13^{* \star *}$ & $0.13^{\star \star \star}$ & $0.13^{* \star *}$ & $0.12^{\star \star *}$ \\
\hline & $(0.024)$ & $(0.025)$ & $(0.024)$ & $(0.024)$ & $(0.014)$ & $(0.016)$ & $(0.015)$ & $(0.015)$ \\
\hline \multirow[t]{2}{*}{ Belgium } & $-0.04^{\star * *}$ & $-0.07^{\star * *}$ & $-0.07^{* * *}$ & $-0.08^{* * *}$ & $-0.08^{* * *}$ & $-0.09^{* * *}$ & $-0.09^{* * *}$ & $-0.10^{* * *}$ \\
\hline & $(0.010)$ & $(0.013)$ & $(0.010)$ & $(0.011)$ & $(0.005)$ & $(0.007)$ & $(0.005)$ & $(0.005)$ \\
\hline \multirow[t]{2}{*}{ Czechia } & $-0.68^{* \star *}$ & $-0.64^{\star * *}$ & $-0.65^{\star * *}$ & $-0.65^{\star \star *}$ & $-0.42^{\star \star \star}$ & $-0.40^{* * *}$ & $-0.40^{\star \star \star}$ & $-0.40^{* * *}$ \\
\hline & $(0.042)$ & $(0.046)$ & $(0.041)$ & $(0.044)$ & $(0.024)$ & $(0.027)$ & $(0.024)$ & $(0.025)$ \\
\hline \multirow[t]{2}{*}{ Switzerland } & $0.47^{\star \star \star}$ & $0.42^{\star * \star}$ & $0.43^{\star \star *}$ & $0.42^{\star \star \star}$ & $0.34^{\star \star *}$ & $0.32^{\star \star \star}$ & $0.32^{* \star *}$ & $0.32^{\star \star *}$ \\
\hline & $(0.028)$ & $(0.033)$ & $(0.030)$ & $(0.032)$ & $(0.027)$ & $(0.030)$ & $(0.028)$ & $(0.029)$ \\
\hline \multirow[t]{2}{*}{ Spain } & $-0.07^{*}$ & -0.05 & -0.04 & -0.04 & $-0.07^{* * *}$ & $-0.05^{*}$ & $-0.05^{*}$ & $-0.05^{*}$ \\
\hline & $(0.035)$ & $(0.040)$ & $(0.042)$ & $(0.041)$ & $(0.024)$ & $(0.028)$ & $(0.029)$ & $(0.029)$ \\
\hline \multirow[t]{2}{*}{ France } & $-0.33^{* * *}$ & $-0.35^{* * *}$ & $-0.36^{* * *}$ & $-0.36^{* * *}$ & $-0.22^{* * *}$ & $-0.24^{* * *}$ & $-0.24^{* * *}$ & $-0.24^{* * *}$ \\
\hline & $(0.007)$ & $(0.008)$ & $(0.007)$ & $(0.007)$ & $(0.004)$ & $(0.003)$ & $(0.003)$ & $(0.003)$ \\
\hline \multirow[t]{2}{*}{ Greece } & $-0.50^{* * *}$ & $-0.52^{\star * *}$ & $-0.52^{\star * *}$ & $-0.50^{* * *}$ & $-0.37^{* * *}$ & $-0.38^{* * *}$ & $-0.38^{* * *}$ & $-0.37^{\star \star *}$ \\
\hline & $(0.043)$ & $(0.035)$ & $(0.039)$ & $(0.040)$ & $(0.035)$ & $(0.030)$ & $(0.033)$ & $(0.033)$ \\
\hline \multirow[t]{2}{*}{ Denmark } & $0.44^{* \star *}$ & $0.39^{\star * \star}$ & $0.39^{\star * *}$ & $0.40^{\star * *}$ & $0.34^{* \star *}$ & $0.32^{* * *}$ & $0.32^{* * *}$ & $0.32^{\star * *}$ \\
\hline & $(0.053)$ & $(0.055)$ & $(0.057)$ & $(0.058)$ & $(0.042)$ & $(0.043)$ & $(0.044)$ & $(0.045)$ \\
\hline \multirow[t]{2}{*}{ Italy } & $-0.20^{* * *}$ & $-0.17^{* * *}$ & $-0.17^{* * *}$ & $-0.17^{* * *}$ & $-0.14^{* * *}$ & $-0.12^{* * *}$ & $-0.12^{* * *}$ & $-0.12^{\star * *}$ \\
\hline & $(0.030)$ & $(0.034)$ & $(0.035)$ & $(0.035)$ & $(0.020)$ & $(0.023)$ & $(0.023)$ & $(0.023)$ \\
\hline \multirow[t]{2}{*}{ Netherlands } & $0.25^{\star \star \star}$ & $0.18^{* \star *}$ & $0.20^{* * *}$ & $0.18^{\star \star \star}$ & $0.10^{\star \star *}$ & $0.06^{\star \star \star}$ & $0.07^{* * *}$ & $0.06^{* * *}$ \\
\hline & $(0.018)$ & $(0.025)$ & $(0.025)$ & $(0.026)$ & $(0.015)$ & $(0.019)$ & $(0.019)$ & $(0.020)$ \\
\hline \multirow[t]{2}{*}{ Poland } & $-0.64^{* * *}$ & $-0.60^{\star * *}$ & $-0.59^{* * *}$ & $-0.59^{* * *}$ & $-0.37^{* * *}$ & $-0.34^{* * *}$ & $-0.34^{* * *}$ & $-0.34^{* * *}$ \\
\hline & $(0.040)$ & $(0.038)$ & $(0.043)$ & $(0.041)$ & $(0.031)$ & $(0.030)$ & $(0.033)$ & $(0.032)$ \\
\hline \multirow[t]{2}{*}{ Sweden } & $0.23^{* * *}$ & $0.16^{* *}$ & $0.16^{* \star}$ & $0.16^{* *}$ & $0.17^{* * *}$ & $0.13^{* * *}$ & $0.14^{* * *}$ & $0.14^{* * *}$ \\
\hline & $(0.061)$ & $(0.070)$ & $(0.067)$ & $(0.069)$ & $(0.042)$ & $(0.048)$ & $(0.046)$ & $(0.047)$ \\
\hline \multirow[t]{2}{*}{ voluntary } & - & $0.19^{\star \star \star}$ & - & - & - & $0.12^{\star \star \star}$ & - & - \\
\hline & & $(0.044)$ & & & & $(0.031)$ & & \\
\hline \multirow[t]{2}{*}{ religion attendance } & - & $0.24^{\star * *}$ & - & - & - & $0.15^{\star \star \star}$ & - & - \\
\hline & & $(0.062)$ & & & & $(0.040)$ & & \\
\hline \multirow[t]{2}{*}{ poitical act. } & - & $0.16^{* * *}$ & - & - & - & $0.11^{* * *}$ & - & - \\
\hline & & $(0.050)$ & & & & $(0.035)$ & & \\
\hline \multirow[t]{2}{*}{ help to friends } & - & $0.14^{* * *}$ & - & - & - & $0.09^{\star \star \star}$ & - & - \\
\hline & & $(0.025)$ & & & & $(0.016)$ & & \\
\hline cared for sick & - & -0.06 & - & - & - & $-0.04^{*}$ & - & - \\
\hline & & $(0.035)$ & & & & $(0.021)$ & & \\
\hline sport/social clubs & - & $0.16^{* * *}$ & - & - & - & $0.09^{* * *}$ & - & - \\
\hline & & $(0.021)$ & & & & $(0.017)$ & & \\
\hline at least one activity & - & - & $0.29^{\star * *}$ & - & - & - & $0.17^{* * *}$ & - \\
\hline & & & $(0.048)$ & & & & $(0.030)$ & \\
\hline sociability & - & - & - & $0.90^{\star \star *}$ & - & - & - & $0.56^{* * *}$ \\
\hline & & & & $(0.157)$ & & & & $(0.104)$ \\
\hline Observations & 30,636 & 30,430 & 30,430 & 30,430 & 30,636 & 30,430 & 30,430 & 30,430 \\
\hline Adj. $R^{2}$ & 0.171 & 0.178 & 0.177 & 0.177 & - & - & - & - \\
\hline Log-Likelihood & -59421 & -58753 & -58772 & -58771 & -55870 & -55268 & -55293 & -55287 \\
\hline$A I C$ & 118867 & 117531 & 117568 & 117567 & 111763 & 110560 & 110611 & 110597 \\
\hline$B I C$ & 118967 & 117631 & 117631 & 117631 & 111863 & 110660 & 110711 & 110697 \\
\hline
\end{tabular}

Notes: [1] Robust standard errors in parentheses clustered by country; [2] ${ }^{* * *} p<0.01,{ }^{* *} p<0.05,{ }^{*} p<0.1$. [3] Reference categories: Age class $=50-54 ;$ Marital Status $=$ Single; Area of Residence $=$ Rural; Country = Germany. [4] All estimations include individual design weights for SHARE wave 2 (w2aci). 
Table 4. Determinants of life satisfaction: altruism

\begin{tabular}{|c|c|c|c|c|}
\hline & $\begin{array}{c}1) \\
\text { OLS } \\
\text { life sat. }\end{array}$ & $\begin{array}{c}\text { OLS } \\
\text { OLS } \\
\text { life meaning }\end{array}$ & $\begin{array}{c}\text { (3) } \\
\text { OPROBIT } \\
\text { life sat. }\end{array}$ & $\begin{array}{c}(4) \\
\text { OPROBIT } \\
\text { life meaning }\end{array}$ \\
\hline female & $\begin{array}{c}0.08^{* *} \\
(0.039)\end{array}$ & $\begin{array}{c}0.01 \\
(0.024)\end{array}$ & $\begin{array}{c}0.06^{* *} \\
(0.028)\end{array}$ & $\begin{array}{c}0.03 \\
(0.045)\end{array}$ \\
\hline logincome & $0.15^{* \star *}$ & $0.04^{* * *}$ & $\begin{array}{l}0.09^{\star \star \star} \\
0.015)\end{array}$ & $0.07^{\star \star \star}$ \\
\hline education years & $\begin{array}{l}0.03^{\star * \star} \\
(0.006)\end{array}$ & $\begin{array}{l}0.02^{* \star \star} \\
(0.005)\end{array}$ & $\begin{array}{l}0.02^{* \star \star} \\
(0.004)\end{array}$ & $\begin{array}{l}0.03^{\star \star \star} \\
(0.008)\end{array}$ \\
\hline household size & $\begin{array}{l}-0.05^{\star *} \\
(0.018)\end{array}$ & $\begin{array}{c}-0.00 \\
(0.007)\end{array}$ & $\begin{array}{l}-0.03^{* * *} \\
(0.012)\end{array}$ & $\begin{array}{c}-0.00 \\
(0.013)\end{array}$ \\
\hline n. of children & $\begin{array}{c}0.01 \\
(0.013)\end{array}$ & $\begin{array}{l}0.03^{* * *} \\
(0.008)\end{array}$ & $\begin{array}{c}0.01 \\
(0.006)\end{array}$ & $\begin{array}{l}0.05^{* * *} \\
(0.014)\end{array}$ \\
\hline n. of grandchildren & $\begin{array}{c}0.01 \\
(0.004)\end{array}$ & $\begin{array}{c}-0.01^{*} \\
(0.003)\end{array}$ & $\begin{array}{c}0.01^{* *} \\
(0.003)\end{array}$ & $\begin{array}{c}-0.01^{*} \\
(0.005)\end{array}$ \\
\hline hrooms & $\begin{array}{l}0.06^{\star * *} \\
(0.018)\end{array}$ & $\begin{array}{c}0.01^{*} \\
(0.005)\end{array}$ & $\begin{array}{l}0.04^{* * *} \\
(0.011)\end{array}$ & $\begin{array}{c}0.03^{* *} \\
(0.012)\end{array}$ \\
\hline bigcity & $\begin{array}{c}0.03 \\
(0.041)\end{array}$ & $\begin{array}{c}-0.01 \\
(0.017)\end{array}$ & $\begin{array}{c}0.02 \\
(0.024)\end{array}$ & $\begin{array}{c}-0.02 \\
(0.026)\end{array}$ \\
\hline suburbs & $\begin{array}{c}-0.04 \\
(0.049)\end{array}$ & $\begin{array}{c}0.02 \\
(0.015)\end{array}$ & $\begin{array}{c}-0.02 \\
(0.026)\end{array}$ & $\begin{array}{c}0.02 \\
(0.031)\end{array}$ \\
\hline largetown & $\begin{array}{c}0.05 \\
(0.044)\end{array}$ & $\begin{array}{c}0.01 \\
(0.013)\end{array}$ & $\begin{array}{c}0.04 \\
(0.028)\end{array}$ & $\begin{array}{c}0.02 \\
(0.024)\end{array}$ \\
\hline smalltown & $\begin{array}{c}0.05 \\
(0.058)\end{array}$ & $\begin{array}{c}0.00 \\
(0.014)\end{array}$ & $\begin{array}{c}0.03 \\
(0.038)\end{array}$ & $\begin{array}{c}-0.00 \\
(0.024)\end{array}$ \\
\hline long term illness & $\begin{array}{c}-0.25^{* * *} \\
(0.024)\end{array}$ & $\begin{array}{c}-0.03^{* * *} \\
(0.009)\end{array}$ & $\begin{array}{c}-0.16^{* * *} \\
(0.015)\end{array}$ & $\begin{array}{c}-0.05^{* * *} \\
(0.019)\end{array}$ \\
\hline limited activities & $\begin{array}{c}-0.59^{* * *} \\
(0.057)\end{array}$ & $\begin{array}{c}-0.16^{\star * *} \\
(0.021)\end{array}$ & $\begin{array}{c}-0.35^{* * *} \\
(0.033)\end{array}$ & $\begin{array}{c}-0.28^{* * *} \\
(0.033)\end{array}$ \\
\hline numb. illnesses & $\begin{array}{c}-0.13^{* * *} \\
(0.015)\end{array}$ & $\begin{array}{c}-0.04^{\star * *} \\
(0.005)\end{array}$ & $\begin{array}{c}-0.08^{\star * \star} \\
(0.009)\end{array}$ & $\begin{array}{c}-0.06^{\star \star *} \\
(0.003)\end{array}$ \\
\hline voluntary altruism & $\begin{array}{l}0.18^{\star * *} \\
(0.055)\end{array}$ & $\begin{array}{c}0.07^{\star *} \\
(0.025)\end{array}$ & $\begin{array}{l}0.12^{\star * \star} \\
(0.040)\end{array}$ & $\begin{array}{l}0.20^{\star \star \star} \\
(0.045)\end{array}$ \\
\hline cared for sick altruism & $\begin{array}{c}-0.06 \\
(0.034)\end{array}$ & $\begin{array}{l}0.04^{* * *} \\
(0.012)\end{array}$ & $\begin{array}{l}-0.04^{* *} \\
(0.019)\end{array}$ & $\begin{array}{l}0.09^{* * *} \\
(0.031)\end{array}$ \\
\hline help to friends altruism & $\begin{array}{l}0.16^{\star \star \star} \\
(0.029)\end{array}$ & $\begin{array}{l}0.10^{\star * \star} \\
(0.022)\end{array}$ & $\begin{array}{l}0.11^{* * *} \\
(0.020)\end{array}$ & $\begin{array}{l}0.24^{* * *} \\
(0.035)\end{array}$ \\
\hline sport/social clubs altruism & $\begin{array}{l}0.15^{\star \star *} \\
(0.019)\end{array}$ & $\begin{array}{l}0.09^{* * *} \\
(0.012)\end{array}$ & $\begin{array}{l}0.08^{\star * *} \\
(0.016)\end{array}$ & $\begin{array}{l}0.18^{* * *} \\
(0.021)\end{array}$ \\
\hline religion attend altruism & $\begin{array}{l}0.23^{\star * \star} \\
(0.073)\end{array}$ & $\begin{array}{l}0.12^{\star * \star} \\
(0.014)\end{array}$ & $\begin{array}{l}0.15^{\star * \star} \\
(0.049)\end{array}$ & $\begin{array}{l}0.24^{\star * \star} \\
(0.022)\end{array}$ \\
\hline political act. altruism & $\begin{array}{c}0.19^{*} \\
(0.088)\end{array}$ & $\begin{array}{c}0.02 \\
(0.049)\end{array}$ & $\begin{array}{c}0.13^{* *} \\
(0.060)\end{array}$ & $\begin{array}{c}0.08 \\
(0.107)\end{array}$ \\
\hline voluntary no altruism & $\begin{array}{c}0.21 \\
(0.124)\end{array}$ & $\begin{array}{c}-0.03 \\
(0.057)\end{array}$ & $\begin{array}{c}0.13 \\
(0.085)\end{array}$ & $\begin{array}{c}-0.02 \\
(0.097)\end{array}$ \\
\hline care for sick no altruism & $\begin{array}{c}-0.05 \\
(0.125)\end{array}$ & $\begin{array}{c}0.02 \\
(0.042)\end{array}$ & $\begin{array}{c}-0.03 \\
(0.087)\end{array}$ & $\begin{array}{c}-0.00 \\
(0.099)\end{array}$ \\
\hline help to friends no altruism & $\begin{array}{c}-0.13 \\
(0.076)\end{array}$ & $\begin{array}{c}-0.01 \\
(0.058)\end{array}$ & $\begin{array}{c}-0.09^{* *} \\
(0.045)\end{array}$ & $\begin{array}{c}-0.06 \\
(0.112)\end{array}$ \\
\hline sport/social clubs no altruism & $\begin{array}{l}0.24^{* * *} \\
(0.034)\end{array}$ & $\begin{array}{l}0.13^{\star * *} \\
(0.031)\end{array}$ & $\begin{array}{l}0.15^{\star * \star} \\
(0.028)\end{array}$ & $\begin{array}{l}0.28^{* * *} \\
(0.091)\end{array}$ \\
\hline religion attend. no altruism & $\begin{array}{l}0.25^{\star \star *} \\
(0.068)\end{array}$ & $\begin{array}{l}0.10^{\star \star *} \\
(0.016)\end{array}$ & $\begin{array}{l}0.14^{* * *} \\
(0.044)\end{array}$ & $\begin{array}{l}0.18^{\star \star *} \\
(0.035)\end{array}$ \\
\hline political act. no altruism & $\begin{array}{c}0.11 \\
(0.102)\end{array}$ & $\begin{array}{c}0.06 \\
(0.051)\end{array}$ & $\begin{array}{c}0.07 \\
(0.078)\end{array}$ & $\begin{array}{c}0.14 \\
(0.143)\end{array}$ \\
\hline marital status dummies & YES & YES & YES & YES \\
\hline country dummies & YES & YES & YES & YES \\
\hline age class dummies & YES & YES & YES & YES \\
\hline $\begin{array}{l}\text { Observations } \\
\text { Adj. } R^{2} \\
\text { Log-Likelihood } \\
\text { AIC } \\
\text { BIC }\end{array}$ & $\begin{array}{c}0.179 \\
0.179 \\
-58747 \\
117518 \\
117618\end{array}$ & $\begin{array}{c}0.130 \\
0.130 \\
-32332 \\
64688 \\
64788\end{array}$ & $\begin{array}{c}0.179 \\
- \\
-55260 \\
110545 \\
110644\end{array}$ & $\begin{array}{c}0.130 \\
- \\
-26165 \\
52355 \\
52454\end{array}$ \\
\hline
\end{tabular}


Table 5. Determinants of life satisfaction and life meaning: social norms and strategic behaviour

\begin{tabular}{|c|c|c|c|c|c|c|c|c|}
\hline & $\begin{array}{c}(1) \\
\text { life sat } \\
\text { Base }\end{array}$ & $\begin{array}{c}(2) \\
\text { life sat } \\
\text { Retired } \\
\end{array}$ & $\begin{array}{c}\text { (3) } \\
\text { life sat } \\
\text { High Norm } \\
\end{array}$ & $\begin{array}{c}(4) \\
\text { life sat } \\
\text { Low Norm } \\
\end{array}$ & $\begin{array}{c}(5) \\
\text { life meaning } \\
\text { Base } \\
\end{array}$ & $\begin{array}{c}(6) \\
\text { life meaning } \\
\text { Retired }\end{array}$ & $\begin{array}{c}(7) \\
\text { life meaning } \\
\text { High Norm }\end{array}$ & $\begin{array}{c}(8) \\
\text { life meaning } \\
\text { Low Norm }\end{array}$ \\
\hline female & $\begin{array}{l}0.09^{*} \\
(0.039)\end{array}$ & $\begin{array}{l}0.08 \\
(0.047)\end{array}$ & $\begin{array}{l}0.12 \\
(0.066)\end{array}$ & $\begin{array}{l}0.07^{*} \\
(0.034)\end{array}$ & $\begin{array}{l}0.01 \\
(0.025)\end{array}$ & $\begin{array}{l}-0.00 \\
(0.032)\end{array}$ & $\begin{array}{l}0.03 \\
(0.028)\end{array}$ & $\begin{array}{l}0.01 \\
(0.029)\end{array}$ \\
\hline logincome & $\begin{array}{l}0.15^{\star * \star} \\
(0.024)\end{array}$ & $\begin{array}{l}0.15^{* * *} \\
(0.027)\end{array}$ & $\begin{array}{l}0.19^{* * *} \\
(0.018)\end{array}$ & $\begin{array}{l}0.14^{\star \star \star} \\
(0.031)\end{array}$ & $\begin{array}{l}0.04^{* * *} \\
(0.009)\end{array}$ & $\begin{array}{l}0.06^{* * *} \\
(0.014)\end{array}$ & $\begin{array}{l}0.03^{* *} \\
(0.011)\end{array}$ & $\begin{array}{l}0.04^{* *} \\
(0.014)\end{array}$ \\
\hline education years & $\begin{array}{l}0.03^{\star * *} \\
(0.006)\end{array}$ & $\begin{array}{l}0.02^{* * *} \\
(0.007)\end{array}$ & $\begin{array}{l}0.01^{* *} \\
(0.005)\end{array}$ & $\begin{array}{l}0.03^{* * *} \\
(0.007)\end{array}$ & $\begin{array}{l}0.01^{* * *} \\
(0.005)\end{array}$ & $\begin{array}{l}0.01^{*} \\
(0.006)\end{array}$ & $\begin{array}{l}0.00 \\
(0.002)\end{array}$ & $\begin{array}{l}0.02^{* * *} \\
(0.005)\end{array}$ \\
\hline household size & $\begin{array}{l}-0.05^{* *} \\
(0.018)\end{array}$ & $\begin{array}{l}-0.03 \\
(0.025)\end{array}$ & $\begin{array}{l}-0.02 \\
(0.011)\end{array}$ & $\begin{array}{l}-0.06^{* *} \\
(0.026)\end{array}$ & $\begin{array}{l}-0.00 \\
(0.007)\end{array}$ & $\begin{array}{l}-0.00 \\
(0.008)\end{array}$ & $\begin{array}{l}0.00 \\
0.03^{* * *}\end{array}$ & $\begin{array}{l}-0.01 \\
0.03^{*}\end{array}$ \\
\hline n. of children & $\begin{array}{l}0.01 \\
(0.013)\end{array}$ & $\begin{array}{l}0.04^{*} \\
(0.022)\end{array}$ & $\begin{array}{l}0.12 \\
0.01\end{array}$ & $\begin{array}{l}0.07^{\star} \\
0.02\end{array}$ & $\begin{array}{l}0.03^{* * *} \\
(0.008)\end{array}$ & $\begin{array}{l}0.03^{\star * *} \\
(0.009)\end{array}$ & $\begin{array}{l}(0.005) \\
-0.01\end{array}$ & $\begin{array}{l}(0.014) \\
-0.01\end{array}$ \\
\hline n. of grandchildren & $\begin{array}{l}0.01 \\
(0.005)\end{array}$ & $\begin{array}{l}-0.00 \\
(0.006)\end{array}$ & $\begin{array}{l}(0.013) \\
0.01\end{array}$ & $\begin{array}{l}(0.019) \\
0.00\end{array}$ & $\begin{array}{l}-0.01^{*} \\
(0.003)\end{array}$ & $\begin{array}{l}-0.01^{*} \\
(0.003)\end{array}$ & $\begin{array}{l}(0.004) \\
0.01\end{array}$ & $\begin{array}{l}(0.005) \\
0.01\end{array}$ \\
\hline hrooms & $\begin{array}{l}0.06^{\star * *} \\
(0.018)\end{array}$ & $\begin{array}{l}0.05^{* *} \\
(0.018)\end{array}$ & $\begin{array}{l}(0.007) \\
0.07^{\star \star *}\end{array}$ & $\begin{array}{l}(0.008) \\
0.06^{\star *}\end{array}$ & $\begin{array}{l}0.01^{*} \\
(0.005)\end{array}$ & $\begin{array}{l}0.01 \\
(0.008)\end{array}$ & $\begin{array}{l}(0.005) \\
0.01\end{array}$ & $\begin{array}{l}(0.006) \\
-0.03\end{array}$ \\
\hline bigcity & $\begin{array}{l}0.03 \\
(0.041)\end{array}$ & $\begin{array}{l}0.08 \\
(0.050)\end{array}$ & $\begin{array}{l}(0.017) \\
0.06^{*}\end{array}$ & $\begin{array}{l}(0.019) \\
-0.02\end{array}$ & $\begin{array}{l}-0.01 \\
(0.017)\end{array}$ & $\begin{array}{l}-0.04 \\
(0.038)\end{array}$ & $\begin{array}{l}(0.015) \\
-0.01\end{array}$ & $\begin{array}{l}(0.027) \\
0.04\end{array}$ \\
\hline suburbs & $\begin{array}{l}-0.04 \\
(0.049)\end{array}$ & $\begin{array}{l}0.10 \\
(0.075)\end{array}$ & $\begin{array}{l}(0.028) \\
-0.11^{* *}\end{array}$ & $\begin{array}{l}(0.050) \\
-0.02\end{array}$ & $\begin{array}{l}0.02 \\
(0.015)\end{array}$ & $\begin{array}{l}0.03^{*} \\
(0.018)\end{array}$ & $\begin{array}{l}(0.028) \\
0.02\end{array}$ & $\begin{array}{l}(0.026) \\
-0.01\end{array}$ \\
\hline largetown & $\begin{array}{l}0.05 \\
(0.044)\end{array}$ & $\begin{array}{l}0.09 \\
(0.082)\end{array}$ & $\begin{array}{l}(0.044) \\
0.05\end{array}$ & $\begin{array}{l}(0.089) \\
0.02\end{array}$ & $\begin{array}{l}0.01 \\
(0.013)\end{array}$ & $\begin{array}{l}0.01 \\
(0.022)\end{array}$ & $\begin{array}{l}(0.034) \\
0.01\end{array}$ & $\begin{array}{l}(0.031) \\
-0.01\end{array}$ \\
\hline smalltown & $\begin{array}{l}0.05 \\
(0.058)\end{array}$ & $\begin{array}{l}0.14 \\
(0.097)\end{array}$ & $\begin{array}{l}(0.093) \\
0.04\end{array}$ & $\begin{array}{l}(0.035) \\
0.03\end{array}$ & $\begin{array}{l}0.00 \\
(0.014)\end{array}$ & $\begin{array}{l}0.01 \\
(0.016)\end{array}$ & $\begin{array}{l}(0.033) \\
-0.04^{\star * *}\end{array}$ & $\begin{array}{l}(0.009) \\
-0.02^{*}\end{array}$ \\
\hline long term illness & $\begin{array}{l}-0.25^{* * *} \\
(0.023)\end{array}$ & $\begin{array}{l}-0.24^{* * *} \\
(0.047)\end{array}$ & $\begin{array}{c}(0.091) \\
-0.25^{\star * *}\end{array}$ & $\begin{array}{l}(0.060) \\
-0.24^{* * *}\end{array}$ & $\begin{array}{l}-0.03^{* * *} \\
(0.009)\end{array}$ & $\begin{array}{l}-0.03^{* *} \\
(0.010)\end{array}$ & $\begin{array}{l}(0.010) \\
-0.14^{\star * *}\end{array}$ & $\begin{array}{c}(0.013) \\
-0.16^{\star * \star}\end{array}$ \\
\hline limited activities & $\begin{array}{l}-0.59^{* * *} \\
(0.057)\end{array}$ & $\begin{array}{l}-0.64^{* * *} \\
(0.034)\end{array}$ & $\begin{array}{l}(0.038) \\
-0.44^{* \star *}\end{array}$ & $\begin{array}{l}(0.030) \\
-0.66^{\star * *}\end{array}$ & $\begin{array}{l}-0.16^{\star * *} \\
(0.021)\end{array}$ & $\begin{array}{l}-0.19^{* * *} \\
(0.027)\end{array}$ & $\begin{array}{l}(0.026) \\
-0.02^{\star * *}\end{array}$ & $\begin{array}{l}(0.036) \\
-0.04^{* \star \star}\end{array}$ \\
\hline numb. illnesses & $\begin{array}{l}-0.13^{\star * \star} \\
(0.015)\end{array}$ & $\begin{array}{l}-0.12^{\star * *} \\
(0.023)\end{array}$ & $\begin{array}{l}(0.046) \\
-0.11^{* * *}\end{array}$ & $\begin{array}{l}(0.074) \\
-0.14^{\star \star \star}\end{array}$ & $\begin{array}{l}-0.04^{\star * \star} \\
(0.005)\end{array}$ & $\begin{array}{l}-0.03^{\star * *} \\
(0.006)\end{array}$ & $\begin{array}{l}(0.005) \\
0.03^{\star \star \star}\end{array}$ & $\begin{array}{l}(0.007) \\
0.03^{*}\end{array}$ \\
\hline other reg actmot & $\begin{array}{l}0.23^{* * *} \\
(0.038)\end{array}$ & $\begin{array}{l}0.31^{* * *} \\
(0.044)\end{array}$ & $\begin{array}{l}0.11^{* *} \\
(0.034)\end{array}$ & $\begin{array}{l}0.37^{* * *} \\
(0.050)\end{array}$ & $\begin{array}{l}0.12^{* * \star} \\
(0.024)\end{array}$ & $\begin{array}{l}0.17^{\star * \star} \\
(0.029)\end{array}$ & 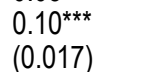 & $\begin{array}{l}0.13^{* *} \\
(0.043)\end{array}$ \\
\hline care for sick altruism & $\begin{array}{l}-0.06 \\
(0.034)\end{array}$ & $\begin{array}{l}-0.05 \\
(0.042)\end{array}$ & $\begin{array}{l}0.01 \\
(0.035)\end{array}$ & $\begin{array}{l}-0.11 \\
(0.060)\end{array}$ & $\begin{array}{l}0.04^{* * *} \\
(0.011)\end{array}$ & $\begin{array}{l}0.04 \\
(0.023)\end{array}$ & $\begin{array}{l}0.02 \\
(0.016)\end{array}$ & $\begin{array}{l}0.07^{* *} \\
(0.027)\end{array}$ \\
\hline sport/social clubs altruism & $\begin{array}{l}0.15^{\star * *} \\
(0.018)\end{array}$ & $\begin{array}{l}0.13^{* * *} \\
(0.019)\end{array}$ & $\begin{array}{l}0.18^{* * *} \\
(0.048)\end{array}$ & $\begin{array}{l}0.10^{* *} \\
(0.042)\end{array}$ & $\begin{array}{l}0.09^{* * *} \\
(0.013)\end{array}$ & $\begin{array}{l}0.11^{* * *} \\
(0.011)\end{array}$ & $\begin{array}{l}0.06^{\star * *} \\
(0.013)\end{array}$ & $\begin{array}{l}0.12^{* * *} \\
(0.025)\end{array}$ \\
\hline religion attend. altruism & $\begin{array}{l}0.24^{\star * *} \\
(0.075)\end{array}$ & $\begin{array}{l}0.31^{* * *} \\
(0.098)\end{array}$ & $\begin{array}{l}0.15^{\star *} \\
(0.049)\end{array}$ & $\begin{array}{l}0.31^{* * *} \\
(0.080)\end{array}$ & $\begin{array}{l}0.12^{* * *} \\
(0.014)\end{array}$ & $\begin{array}{l}0.12^{* * *} \\
(0.033)\end{array}$ & $\begin{array}{l}0.11^{\star *} \\
(0.036)\end{array}$ & $\begin{array}{l}0.13^{\star * *} \\
(0.018)\end{array}$ \\
\hline political act. altruism & $\begin{array}{l}0.20^{* *} \\
(0.084)\end{array}$ & $\begin{array}{l}0.24^{* * *} \\
(0.070)\end{array}$ & $\begin{array}{l}0.13 \\
(0.116)\end{array}$ & $\begin{array}{l}0.32^{* *} \\
(0.117)\end{array}$ & $\begin{array}{l}0.02 \\
(0.045)\end{array}$ & $\begin{array}{l}0.06^{* * *} \\
(0.019)\end{array}$ & $\begin{array}{l}-0.01 \\
(0.053)\end{array}$ & $\begin{array}{l}0.07^{*} \\
(0.036)\end{array}$ \\
\hline voluntary no altruism & $\begin{array}{l}0.21 \\
(0.125)\end{array}$ & $\begin{array}{l}0.23 \\
(0.161)\end{array}$ & $\begin{array}{l}0.36^{*} \\
(0.166)\end{array}$ & $\begin{array}{l}0.01 \\
(0.075)\end{array}$ & $\begin{array}{l}-0.03 \\
(0.057)\end{array}$ & $\begin{array}{l}-0.03 \\
(0.119)\end{array}$ & $\begin{array}{l}-0.06 \\
(0.080)\end{array}$ & $\begin{array}{l}0.01 \\
(0.079)\end{array}$ \\
\hline care for sick no altruism & $\begin{array}{l}-0.04 \\
(0.124)\end{array}$ & $\begin{array}{l}0.13 \\
(0.214)\end{array}$ & $\begin{array}{l}-0.04 \\
(0.243)\end{array}$ & $\begin{array}{l}-0.09 \\
(0.300)\end{array}$ & $\begin{array}{l}0.03 \\
(0.041)\end{array}$ & $\begin{array}{l}0.07 \\
(0.080)\end{array}$ & $\begin{array}{l}0.10^{* *} \\
(0.030)\end{array}$ & $\begin{array}{l}-0.04 \\
(0.063)\end{array}$ \\
\hline help to friends no altruism & $\begin{array}{l}-0.13 \\
(0.079)\end{array}$ & $\begin{array}{l}-0.13 \\
(0.147)\end{array}$ & $\begin{array}{l}-0.21 \\
(0.145)\end{array}$ & $\begin{array}{l}-0.10 \\
(0.122)\end{array}$ & $\begin{array}{l}-0.02 \\
(0.058)\end{array}$ & $\begin{array}{l}0.02 \\
(0.039)\end{array}$ & $\begin{array}{l}-0.04 \\
(0.039)\end{array}$ & $\begin{array}{l}0.00 \\
(0.086)\end{array}$ \\
\hline sport/social clubs no altruism & $\begin{array}{l}0.25^{* * *} \\
(0.033)\end{array}$ & $\begin{array}{l}0.33^{* * *} \\
(0.104)\end{array}$ & $\begin{array}{l}0.22^{* * *} \\
(0.042)\end{array}$ & $\begin{array}{l}0.24^{* * *} \\
(0.039)\end{array}$ & $\begin{array}{l}0.13^{* * *} \\
(0.028)\end{array}$ & $\begin{array}{l}0.18^{* * *} \\
(0.027)\end{array}$ & $\begin{array}{l}0.04 \\
(0.026)\end{array}$ & $\begin{array}{l}0.18^{* * *} \\
(0.017)\end{array}$ \\
\hline religion attend. no altruism & $\begin{array}{l}0.25^{\star * \star} \\
(0.065)\end{array}$ & $\begin{array}{l}0.38^{* * *} \\
(0.120)\end{array}$ & $\begin{array}{l}0.14^{* *} \\
(0.055)\end{array}$ & $\begin{array}{l}0.30^{\star *} \\
(0.106)\end{array}$ & $\begin{array}{l}0.10^{* * *} \\
(0.017)\end{array}$ & $\begin{array}{l}0.12^{* \star \star} \\
(0.025)\end{array}$ & $\begin{array}{l}0.09^{\star * *} \\
(0.022)\end{array}$ & $\begin{array}{l}0.09^{\star * *} \\
(0.018)\end{array}$ \\
\hline political act. no altruism & $\begin{array}{l}0.11 \\
(0.100)\end{array}$ & $\begin{array}{l}0.16 \\
(0.115)\end{array}$ & $\begin{array}{l}0.17 \\
(0.138)\end{array}$ & $\begin{array}{l}0.06 \\
(0.136)\end{array}$ & $\begin{array}{l}0.06 \\
(0.050)\end{array}$ & $\begin{array}{l}0.01 \\
(0.047)\end{array}$ & $\begin{array}{l}0.10^{* *} \\
(0.042)\end{array}$ & $\begin{array}{l}0.02 \\
(0.108)\end{array}$ \\
\hline marital status dummies & YES & YES & YES & YES & YES & YES & YES & YES \\
\hline country dummies & YES & YES & YES & YES & YES & YES & YES & YES \\
\hline age class dummies & YES & YES & YES & YES & YES & YES & YES & YES \\
\hline $\begin{array}{l}\text { Observations } \\
\text { Adj. } R^{2} \\
\text { Log-Likelihood } \\
\text { AIC } \\
\text { BIC }\end{array}$ & $\begin{array}{l}30,430 \\
0.179 \\
-58741 \\
117505 \\
117605\end{array}$ & $\begin{array}{l}15,860 \\
0.178 \\
-30993 \\
62010 \\
62102\end{array}$ & $\begin{array}{l}15,025 \\
0.154 \\
-27898 \\
55810 \\
55864\end{array}$ & $\begin{array}{l}15,405 \\
0.178 \\
-30209 \\
60433 \\
60494\end{array}$ & $\begin{array}{l}30,295 \\
0.129 \\
-32326 \\
64675 \\
64775\end{array}$ & $\begin{array}{l}15,789 \\
0.138 \\
-17142 \\
34309 \\
34401\end{array}$ & $\begin{array}{l}14,936 \\
0.110 \\
-15508 \\
31031 \\
31084\end{array}$ & $\begin{array}{l}15,359 \\
0.131 \\
-15508 \\
33119 \\
33180\end{array}$ \\
\hline
\end{tabular}


Table 6a. OLS regressions on the impact of synthetic other regarding sociability variables on life satisfaction

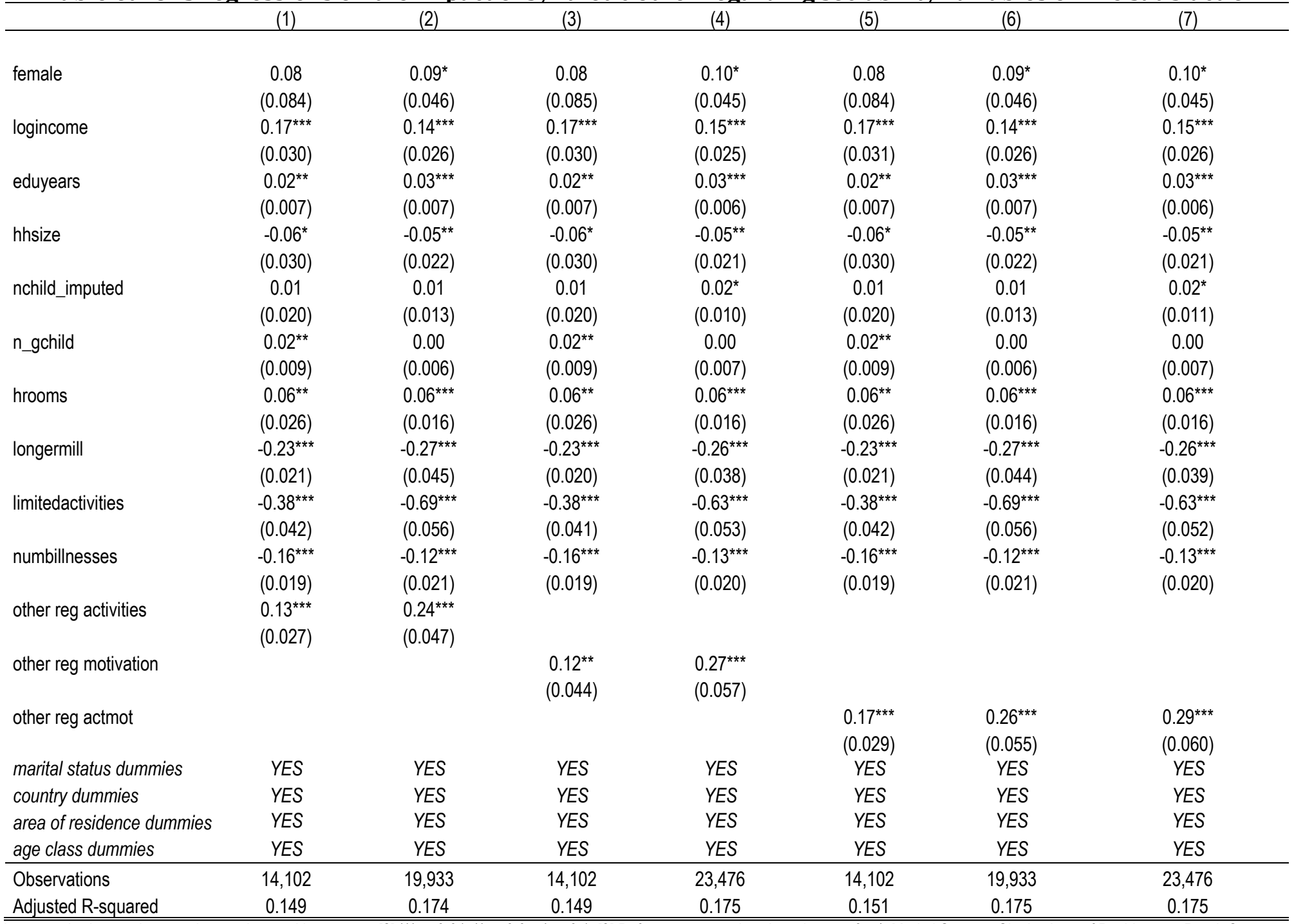

Notes: [1] Robust standard errors in parentheses clustered by country; [2] ${ }^{* \star *} p<0.01,{ }^{* *} p<0.05,{ }^{*} p<0.1$. [3] Reference categories: Age class $=50-54 ;$ Marital Status $=$ Single; Area of Residence $=$ Rural; Country $=$ Germany. [4] 1), 3) and 5) only individuals doing at least one social activity; 2) and 6) individuals doing self-regarding social activities are excluded (i.e. activities different from helping friends/neighbours or voluntary/charity work); 4) and 7) individuals doing other regarding activities with self-regarding motivations are excluded. [5] All estimations include individual design weights for SHARE wave 2 (w2aci). 
Table 6b. IV regressions on the impact of synthetic other regarding sociability variables on life satisfaction

\begin{tabular}{|c|c|c|c|c|c|c|c|c|}
\hline & (1) & (2) & (3) & (4) & (5) & (6) & (7) & (8) \\
\hline at least one activity & $\begin{array}{l}0.77^{* * *} \\
(0.223)\end{array}$ & & & & & & & \\
\hline other reg activities & & $\begin{array}{c}0.92^{* *} \\
(0.359)\end{array}$ & $\begin{array}{l}1.89^{\star * *} \\
(0.530)\end{array}$ & & & & & \\
\hline other reg motivation & & & & $\begin{array}{c}1.12^{\star *} \\
(0.442)\end{array}$ & $\begin{array}{l}0.94^{\star * *} \\
(0.303)\end{array}$ & & & \\
\hline other reg actmot & & & & & & $\begin{array}{c}0.85^{\star *} \\
(0.346)\end{array}$ & $\begin{array}{l}1.88^{* * *} \\
(0.571)\end{array}$ & $\begin{array}{l}1.33^{* * *} \\
(0.409)\end{array}$ \\
\hline CONTROLS & YES & YES & YES & YES & YES & YES & YES & YES \\
\hline Obs. & 27,066 & 12,711 & 17,642 & 12,711 & 20,774 & 12,711 & 17,642 & 20,774 \\
\hline Adj $R^{2}$ & $\begin{array}{c}0.169 \\
\text { at least }\end{array}$ & 0.100 & 0.097 & 0.085 & 0.161 & 0.116 & 0.106 & 0.141 \\
\hline Instrumented var. & one & other reg activities & other reg activities & other reg motivation & other reg motivation & other reg actmot & other reg actmot & other reg actmot \\
\hline Weak id. test, F & 146.2 & 39.12 & 33.96 & 35.60 & 78.92 & 40.21 & 30.08 & 44.48 \\
\hline Hansen test, $p$ & 0.370 & 0.767 & 0.0851 & 0.581 & 0.0798 & 0.874 & 0.113 & 0.241 \\
\hline Endogeneity test, p: & 0.0290 & 0.0148 & 0.000743 & 0.0211 & 0.0272 & 0.0332 & 0.00188 & 0.00824 \\
\hline
\end{tabular}


Figure 1. Life Satisfaction

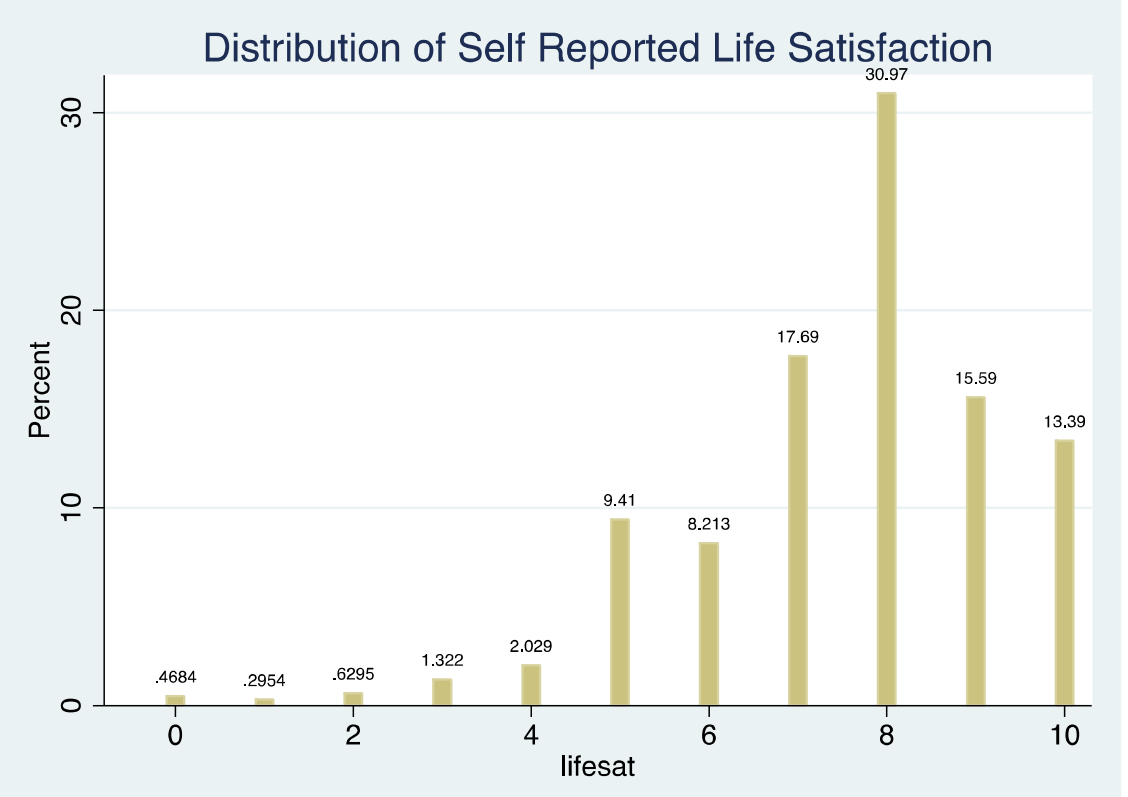

Figure 2. Sociability by country

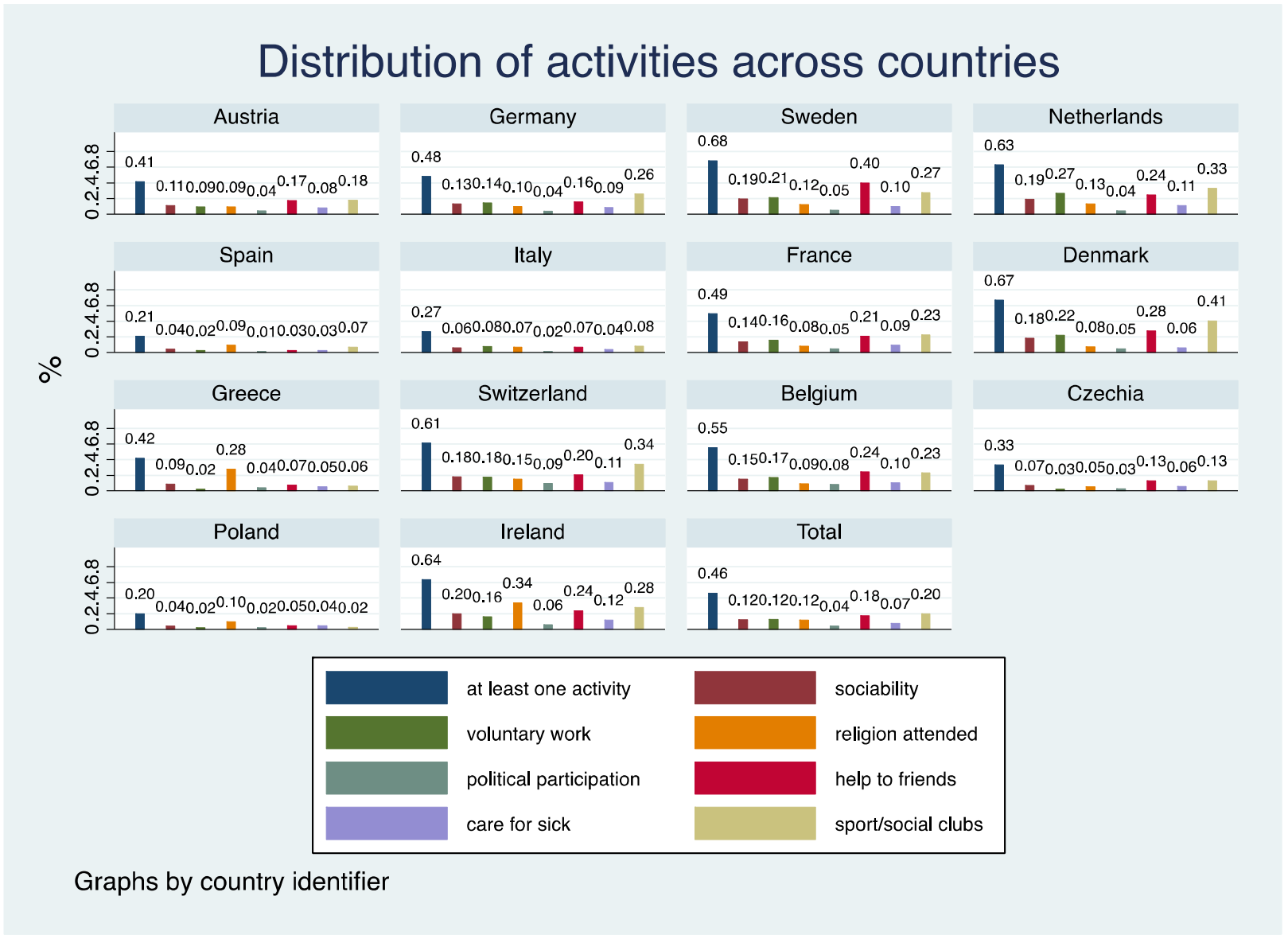




\section{Figure 3a - Sensitivity Analysis (at least one activity)}
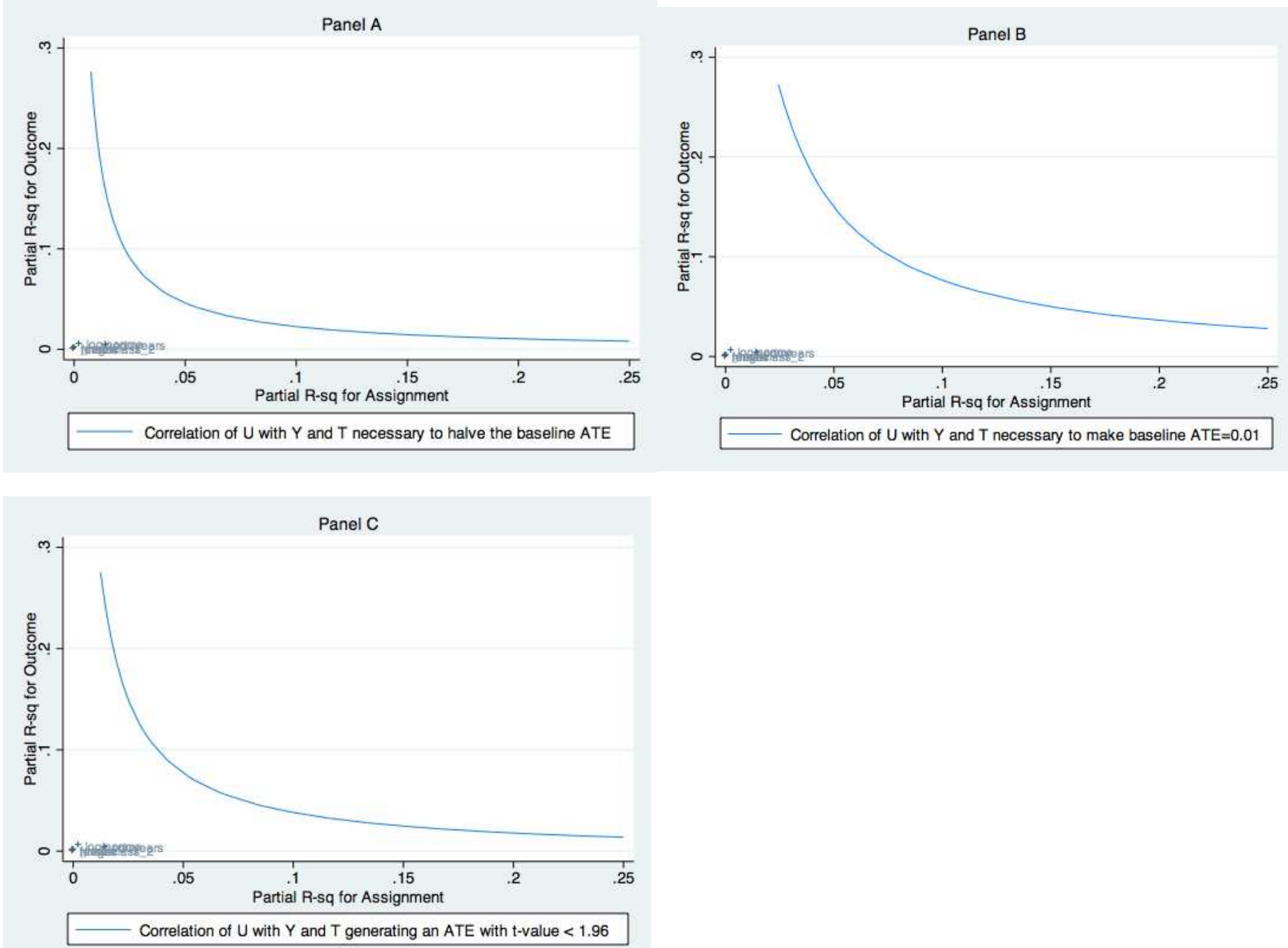

Notes: [1] We use the ISA program for the general sensitivity analysis (GSA) developed by Hamada (2012) which is built upon Imbens (2003)'s paper. The GSA does not hinge on the binary distributional assumption of $U$ as in Imbens (2003) while generating very similar results. [2] The "+" signs are the partial $R^{2}$ values for the $X$ covariates of the baseline model, plotted according to the additional explanatory power of the covariate for $T$ (at_least_one_activity, horizontal axis) and for $Y$ (life_sat, vertical axis); the axis measures variations in the $R^{2}$ from adding that $X$-regressor to the baseline model. [3] The solid curve is the set of partial $R^{2}$ for $U$ and represents where the unobserved covariate would have enough correlation with both treatment and educational outcomes to modify magnitude and/or significance of the baseline ATE. [4] All estimations include individual design weights for SHARE wave 2 (w2aci). 
Figure 3b - Sensitivity Analysis (at least one other regarding activity and motivation)
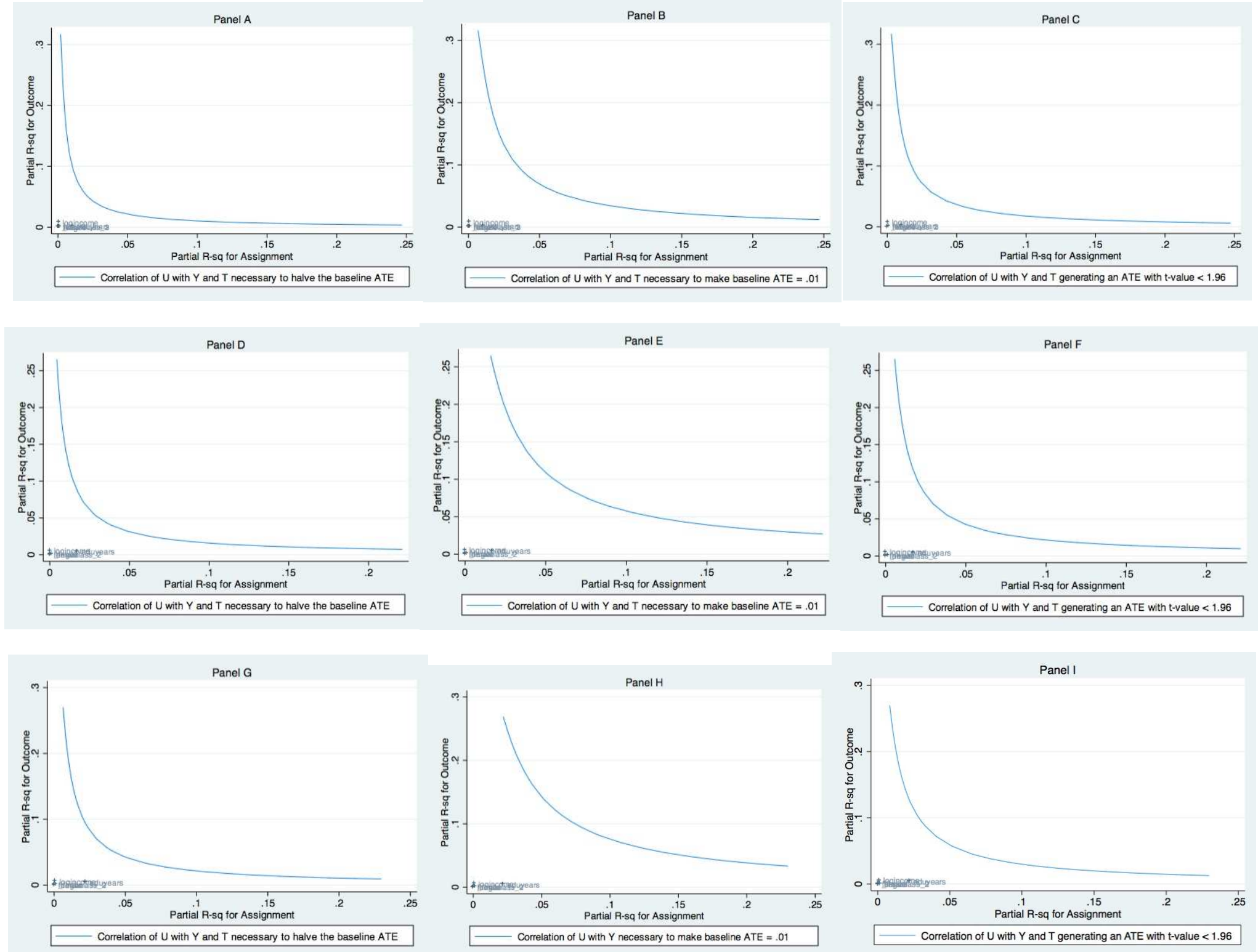

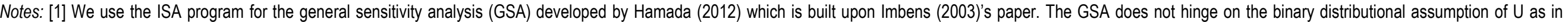

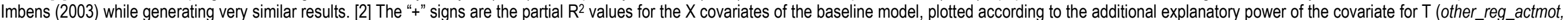

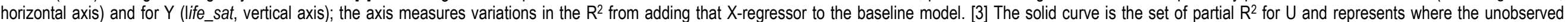

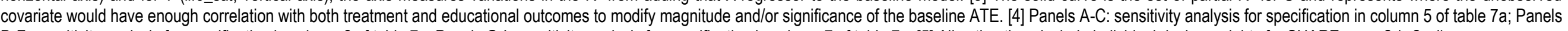
D-F: sensitivity analysis for specification in column 6 of table 7a; Panels G-l: sensitivity analysis for specification in column 7 of table 7a. [5] All estimations include individual design weights for SHARE wave 2 (w2aci). 
Table A.1. Marginal Effects

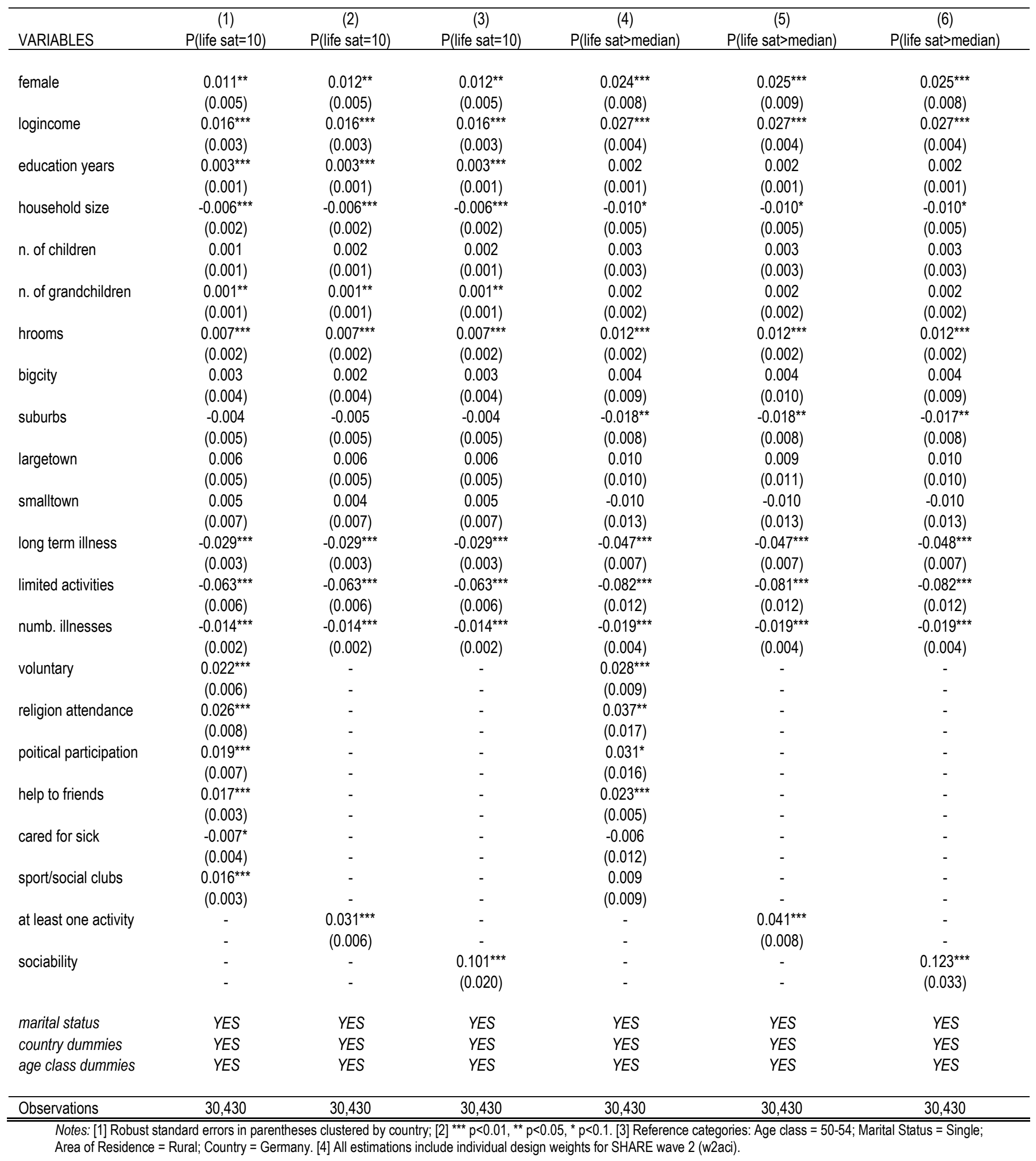


Table A.2. Determinants of life satisfaction (robustness check)

\begin{tabular}{|c|c|c|c|c|c|c|}
\hline Dep var: & $\begin{array}{c}1) \\
\text { happypred }\end{array}$ & $\begin{array}{c}(2) \\
\text { happypred }\end{array}$ & $\begin{array}{c}(3) \\
\text { avg_lifesat }\end{array}$ & $\begin{array}{c}\text { (4) } \\
\text { avg_lifesat }\end{array}$ & $\begin{array}{l}\text { (5) } \\
\text { pca }\end{array}$ & $\begin{array}{l}\text { (6) } \\
\text { pca }\end{array}$ \\
\hline female & $\begin{array}{l}-0.01 \\
(0.050)\end{array}$ & $\begin{array}{c}-0.01 \\
(0.050)\end{array}$ & $\begin{array}{c}-0.01 \\
(0.024)\end{array}$ & $\begin{array}{c}-0.01 \\
(0.024)\end{array}$ & $\begin{array}{c}-0.04 \\
(0.091)\end{array}$ & $\begin{array}{c}-0.03 \\
(0.092)\end{array}$ \\
\hline logincome & $\begin{array}{l}0.11^{* * *} \\
(0.025)\end{array}$ & $\begin{array}{l}0.11^{* * *} \\
(0.025)\end{array}$ & $\begin{array}{l}0.05^{\star * *} \\
(0.012)\end{array}$ & $\begin{array}{l}0.05^{\star \star *} \\
(0.012)\end{array}$ & $\begin{array}{l}0.18^{* * *} \\
(0.043)\end{array}$ & $\begin{array}{l}0.17^{\star * *} \\
(0.044)\end{array}$ \\
\hline education years & $\begin{array}{l}0.04^{* \star *} \\
(0.006)\end{array}$ & $\begin{array}{l}0.03^{* * *} \\
(0.006)\end{array}$ & $\begin{array}{l}0.02^{* \star *} \\
(0.003)\end{array}$ & $\begin{array}{l}0.01^{* \star *} \\
(0.003)\end{array}$ & 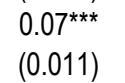 & $\begin{array}{l}0.06^{\star \star *} \\
(0.011)\end{array}$ \\
\hline household size & $\begin{array}{l}-0.05^{\star * *} \\
(0.009)\end{array}$ & $\begin{array}{l}-0.05^{\star \star *} \\
(0.009)\end{array}$ & $\begin{array}{l}-0.03^{* * *} \\
(0.005)\end{array}$ & $\begin{array}{l}-0.03^{* * *} \\
(0.004)\end{array}$ & $\begin{array}{l}-0.08^{* \star *} \\
(0.012)\end{array}$ & $\begin{array}{l}-0.07^{* * *} \\
(0.011)\end{array}$ \\
\hline n. of children & $\begin{array}{c}0.00 \\
(0.009)\end{array}$ & $\begin{array}{c}0.00 \\
(0.008)\end{array}$ & $\begin{array}{l}-0.00 \\
(0.004)\end{array}$ & $\begin{array}{c}-0.00 \\
(0.004)\end{array}$ & $\begin{array}{c}0.02 \\
(0.015)\end{array}$ & $\begin{array}{c}0.02 \\
(0.015)\end{array}$ \\
\hline n. of grandchildren & $\begin{array}{l}-0.00 \\
(0.004)\end{array}$ & $\begin{array}{c}-0.00 \\
(0.004)\end{array}$ & $\begin{array}{c}-0.00 \\
(0.002)\end{array}$ & $\begin{array}{c}-0.00 \\
(0.002)\end{array}$ & $\begin{array}{c}-0.01 \\
(0.006)\end{array}$ & $\begin{array}{l}-0.00 \\
(0.006)\end{array}$ \\
\hline hrooms & $\begin{array}{l}0.05^{\star \star *} \\
(0.014)\end{array}$ & $\begin{array}{l}0.05^{\star * *} \\
(0.011)\end{array}$ & $\begin{array}{l}0.02^{* * *} \\
(0.005)\end{array}$ & $\begin{array}{l}0.02^{* * *} \\
(0.004)\end{array}$ & $\begin{array}{l}0.08^{* * *} \\
(0.024)\end{array}$ & $\begin{array}{l}0.07^{\star \star *} \\
(0.020)\end{array}$ \\
\hline bigcity & $\begin{array}{l}-0.04^{* *} \\
(0.020)\end{array}$ & $\begin{array}{c}-0.03 \\
(0.018)\end{array}$ & $\begin{array}{c}-0.02 \\
(0.014)\end{array}$ & $\begin{array}{c}-0.02 \\
(0.011)\end{array}$ & $\begin{array}{c}-0.05 \\
(0.046)\end{array}$ & $\begin{array}{c}-0.02 \\
(0.043)\end{array}$ \\
\hline suburbs & $\begin{array}{c}0.02 \\
(0.025)\end{array}$ & $\begin{array}{c}0.03 \\
(0.024)\end{array}$ & $\begin{array}{c}0.00 \\
(0.014)\end{array}$ & $\begin{array}{c}0.01 \\
(0.013)\end{array}$ & $\begin{array}{c}0.04 \\
(0.055)\end{array}$ & $\begin{array}{c}0.06 \\
(0.050)\end{array}$ \\
\hline largetown & $\begin{array}{c}-0.01 \\
(0.037)\end{array}$ & $\begin{array}{c}0.01 \\
(0.029)\end{array}$ & $\begin{array}{c}0.00 \\
(0.018)\end{array}$ & $\begin{array}{c}0.01 \\
(0.015)\end{array}$ & $\begin{array}{c}-0.01 \\
(0.075)\end{array}$ & $\begin{array}{c}0.02 \\
(0.062)\end{array}$ \\
\hline smalltown & $\begin{array}{c}0.01 \\
(0.048)\end{array}$ & $\begin{array}{c}0.02 \\
(0.040)\end{array}$ & $\begin{array}{c}0.01 \\
(0.029)\end{array}$ & $\begin{array}{c}0.01 \\
(0.025)\end{array}$ & $\begin{array}{c}0.03 \\
(0.097)\end{array}$ & $\begin{array}{c}0.05 \\
(0.082)\end{array}$ \\
\hline long term illness & $\begin{array}{l}-0.12^{* * *} \\
(0.022)\end{array}$ & $\begin{array}{l}-0.13^{* \star *} \\
(0.023)\end{array}$ & $\begin{array}{l}-0.05^{\star * *} \\
(0.011)\end{array}$ & $\begin{array}{l}-0.06^{* * *} \\
(0.012)\end{array}$ & $\begin{array}{l}-0.22^{* * *} \\
(0.040)\end{array}$ & $\begin{array}{l}-0.22^{* * *} \\
(0.041)\end{array}$ \\
\hline limited activities & $\begin{array}{l}-0.50^{* * *} \\
(0.055)\end{array}$ & $\begin{array}{l}-0.49^{* \star *} \\
(0.055)\end{array}$ & $\begin{array}{l}-0.27^{* * *} \\
(0.025)\end{array}$ & $\begin{array}{l}-0.26^{* * *} \\
(0.025)\end{array}$ & $\begin{array}{l}-1.01^{* * *} \\
(0.103)\end{array}$ & $\begin{array}{l}-0.99^{* * *} \\
(0.102)\end{array}$ \\
\hline numb. illnesses & $\begin{array}{l}-0.11^{* \star *} \\
(0.004)\end{array}$ & $\begin{array}{l}-0.11^{* * *} \\
(0.004)\end{array}$ & $\begin{array}{l}-0.05^{\star * \star} \\
(0.003)\end{array}$ & $\begin{array}{l}-0.06^{* * *} \\
(0.003)\end{array}$ & $\begin{array}{l}-0.21^{* * *} \\
(0.008)\end{array}$ & $\begin{array}{l}-0.21^{* * *} \\
(0.008)\end{array}$ \\
\hline voluntary & - & $\begin{array}{l}0.17^{\star * *} \\
(0.025)\end{array}$ & - & $\begin{array}{l}0.09^{\star * *} \\
(0.012)\end{array}$ & - & $\begin{array}{l}0.33^{* * *} \\
(0.044)\end{array}$ \\
\hline religion attendance & - & $\begin{array}{l}0.13^{* * *} \\
(0.019)\end{array}$ & - & $\begin{array}{l}0.06^{* * *} \\
(0.016)\end{array}$ & - & $\begin{array}{l}0.22^{* * *} \\
(0.040)\end{array}$ \\
\hline political participation & - & $\begin{array}{c}0.05 \\
(0.062)\end{array}$ & - & $\begin{array}{c}0.03 \\
(0.024)\end{array}$ & - & $\begin{array}{c}0.11 \\
(0.113)\end{array}$ \\
\hline help to friends & - & 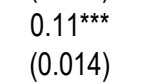 & - & $\begin{array}{l}0.05^{\star * *} \\
(0.007)\end{array}$ & - & $\begin{array}{l}0.26^{* \star *} \\
(0.027)\end{array}$ \\
\hline cared for sick & - & $\begin{array}{l}-0.05 \\
(0.037)\end{array}$ & - & $\begin{array}{l}-0.06^{* \star *} \\
(0.014)\end{array}$ & - & $\begin{array}{c}-0.09 \\
(0.059)\end{array}$ \\
\hline sport/social clubs & - & $\begin{array}{l}0.18^{\star * *} \\
(0.018)\end{array}$ & - & $\begin{array}{l}0.10^{* * *} \\
(0.009)\end{array}$ & - & $\begin{array}{l}0.37^{* * *} \\
(0.033)\end{array}$ \\
\hline marital status dummies & YES & YES & YES & YES & YES & YES \\
\hline country dummies & YES & YES & YES & YES & YES & YES \\
\hline age class dummies & YES & YES & YES & YES & YES & YES \\
\hline Observations & 29,540 & 29,359 & 30,769 & 30,564 & 29,540 & 29,359 \\
\hline Adj. $R^{2}$ & 0.304 & 0.314 & 0.307 & 0.318 & 0.324 & 0.335 \\
\hline$A I C$ & 80724 & 79714 & 39959 & 39110 & 115955 & 114613 \\
\hline$B I C$ & 80823 & 79813 & 40059 & 39210 & 116054.2 & 114712.2 \\
\hline
\end{tabular}

Notes: [1] Robust standard errors in parentheses clustered by country; [2] ${ }^{\star \star *} p<0.01,{ }^{* \star} p<0.05,{ }^{*} p<0.1$. [3] Reference categories: Age class = 50-54; Marital Status = Single; Area of Residence $=$ Rural; Country $=$ Germany. [3] Happypred: predicted dependent variable of the life satisfaction (lifesat) variable on the 11 life satisfaction subcomponents enumerated in section 4.1; [4] avg_lifesat: unweighted average of the 11 life satisfaction subcomponents; [5] pca: first principal component of the11 life satisfaction subcomponents. [6] All estimations include individual design weights for SHARE wave 2 (w2aci). 